\title{
AMNISTÍAS Y DERECHO INTERNACIONAL EN PERSPECTIVA HISTÓRICA: BARTOLOMÉ DE LAS CASAS VS. HUGO GROCIO
}

\author{
ANMISTIES AND INTERNATIONAL LAW FROM AN HISTORIAL \\ PERSPECTIVE: BARTOLOMÉ DE LAS CASAS V. HUGO GROCIO
}

\author{
Víctor M. SÁNCHEZ \\ Universitat Oberta de Catalunya
}

Fecha de recepción: 3-7-19

Fecha de aceptación: 12-2-20

Resumen: Toda amnistía genera un conflicto de valores de difícil solución. ¿Cuál es el "bien" a priorizar en las circunstancias que facilitan la propuesta de amnistías? ¿Castigar penalmente los ilícitos más graves u ofrecer puentes de plata que faciliten la paz a costa de la obligación de castigo? En el pensamiento occidental hubo un momento crítico en la racionalización de la 'validez' filosóficojurídica de esta figura. Las Casas formuló la primera teorización sobre la validez limitada de las amnistías a partir de su teoría del 'pacto social'. Un siglo después Grocio respondió con la teoría del 'dominio eminente' del soberano que propugnaba la validez de cualquier amnistía fijada en tratados por razón de su utilidad pública. La postura grociana se impuso hasta finales del s. XX.

Abstract: Any amnesty generates a conflict of values that is difficult to solve. What is the "good" to prioritize in the circumstances that facilitate the proposal of amnesties? Punishing the most serious crimes or to easy the restoration of peace at the expense of the obligation of punishment? In Thought history there was a critical moment in the rationalization of the philosophical-legal 'validity' of the amnesty. Las Casas formulated the first theory about the conditional validity of amnesties based on his theory of the 'social pact'. A century later Grotius responded with the 'eminent domain' theory of the sovereign who affirmed the validity of any amnesty fixed in treaties because of its public utility. The grotian position prevailed until the end of s. XX.

Palabras clave: amnistía, pacto social, dominio eminente, Derecho internacional Keywords: amnesty, social pact, eminent domain, international Law

ISSN: 1133-0937

DERECHOS Y LIBERTADES

DOI: https://doi.org/10.20318/dyl.2021.5853

Número 44, Época II, enero 2021, pp. 167-208 


\section{INTRODUCCIÓN}

Los ss. XVI y XVII marcan el primer momento en que dos juristas sostienen una controversia sobre la validez de las amnistías de la época. Sus efectos, en apariencia, se podían extender tanto a amnistías internas como internacionales. Las voces de Las Casas y Grocio son opuestas en un aspecto teorético nuclear previo que afecta a sus conclusiones. Las Casas es un contractualista de raíz católica que sitúa el origen del poder soberano en el consentimiento del pueblo y limita el alcance de las potestades soberanas. En contraste, el protestante Grocio, pluralista, justifica y acepta modos no contractualistas de legitimar el origen de la soberanía y expande las manifestaciones de la summa potestas. Estos modos discrepantes de entender el origen de la soberanía condujeron a otras contraposiciones. Donde se apartan más sus posiciones es donde la soberanía se exhibe con mayor desnudez: la facultad para establecer que lo que una ley prohibía debía permanecer impune. Evidentemente, dicha controversia jurídico-moral sólo tuvo lugar en el plano intelectual; Las Casas murió en 1566; Grocio nació en 1583. Pero aunque no cite a Las Casas, la forma de abordar la soberanía en el de Delft sugiere que debió leer sus escritos. Entender las claves de la disputa obliga a hacer diversas aproximaciones históricas. Primero, a describir momentos muy anteriores en los que ya se había manifestado o regulado la potestad pública de adoptar amnistías. Segundo, a detallar qué tipo de amnistías formaban parte de la praxis en la época de ambos. Analizadas las respectivas teorías siempre cabe preguntarse en qué medida sus ideas aportan algo de luz al debate actual sobre la validez de las amnistías.

\section{PERSPECTIVA HISTÓRICA: PAZ Y AMNISTÍA}

\subsection{III-I Milenio a. C.: de la Edad de Bronce al Mundo Grecorromano}

La concesión de amnistías es antiquísima. En derecho interno se remonta al primer registro escrito de normas políticas, las Leyes de URU-KA-gina (2380 a. C.) del Reino de Lagash (Mesopotamia): «para los ciudadanos de Lagash (...) el ladrón, el asesino- él los sacó de la prisión y estableció su libertad" ${ }^{1}$. En el derecho internacional también se recoge una amnistía en el primer tratado de paz bien documentado de

Texto en D. FRAYNE, Pre-Sargonic Period (2700-2350 BC), Royal Inscriptions of Mesopotamia, Early Periods Volume 1, Toronto, Buffalo y Londres, 2004, columna xii 12-22, p. 264. Al respecto, V. M. SÁNCHEZ, Migraciones, refugiados y amnistía en el derecho internacional del Antiguo Oriente Medio, II Milenio a. C., Tecnos, 2016. 
la Historia, el Tratado de Qadesh (1259 a. C.)². Hay así algo fundacional en la aprobación de amnistías. En el siguiente milenio, dentro del mundo grecorromano es posible identificar decenas de amnistías de una u otra naturaleza o alcance. La más famosa es la Atenas del 403 a. C. en la que, dentro del synthéke que daba fin a su guerra civil se puso en vigor una amnistía ${ }^{3}$. El rasgo descollante de las amnistías atenienses es su aprobación por medio de actos legislativos de la Asamblea, los 'pséphismata'. Roma también aprobaría, siguiendo el ejemplo ateniense ${ }^{4}$, amnistías o perdones tanto en sus guerras civiles como en las libradas en el exterior ${ }^{5}$. Un botón de muestra sería la Lex Plautia de reditu Lepidanorum (70 a. C.) que permitió regresar a Roma a los proscritos de la guerra civil del bando perdedor liderado por Lépido y Sertorio ${ }^{6}$. La facultad de aprobar amnistías se reconoce en el Corpus Iuris Civilis (529 d. C.) ${ }^{7}$ a todos los órganos que ejercieron los máximos poderes en Roma bajo uno u otro régimen político. Al Emperador se le habilita el ejercicio de "todo el imperio y potestad" para otorgar beneficios o derechos especiales a personas en concreto (Instituta 1, 2, 6) inclusive los que emanen de su 'divina indulgentia' (Digesto I IV 3). En Cod. Iust. IX 23, 5 se hace una referencia explícita a la capacidad de la ley -aprobada por pueblo- o de los senadocunsultos -leyes aprobadas por el Senado- ${ }^{8}$ de establecer amnistías: "Cum lex in praetorium quid indulgent, in futurum vetat". La característica más destacable del modelo romano es el ligamen claro de esta facultad a la soberanía, fuere quién fuere quien la ostentara. Quien ejerce el imperio ostenta la potestad máxima de condere lege, y aunque creaba leyes ordinarias para enjuiciar hechos futuros podía también legislar sobre los hechos del pasado eliminando los efectos de leyes previas. Otro rasgo interesante del derecho romano es que no desarrolló normas ex ante que cirscunscribieran de alguna forma la concesión de amnistías. Era la manifestación más extrema

2 H. GENZ y D. MIELKE, Insigths into Hittite History and Archaeology, Colloquia Antiqua, Meeters, 2011, p. 318; K. HORST, "From War to Eternal Peace: Ramesses II and Khattushili III", Canadian Society for Mesopotamian Studies, no 37, 2002, p. 52.; H. BREASTED, Ancient records of Egypt, vol. III, 1906, §§ 370-91; G. BECHMAN, Hittite diplomatic texts, Atalanta, 1996, p. 94.

3 ARISTÓTELES, Constitución de los atenienses, Gredos, 1984, pár. 40. Sobre la primera amnistía de Atenas, V. M. SÁNCHEZ, Amnistía imperio del derecho y exilio en el Arcontado de Solon (594 a. C.), Tecnos 2018.

4 M. T. CICERONIS, M. Antonium oratio Philippica Prima, en http://www.thelatinlibrary. com/cicero/phil.shtml

5 Enciclopedia Moderna de España, Fr. P. MELLADO, Madrid, vol II, 1851, columnas 377-378,

6 J. ALISON, Rome after Sulla, Bloomsbury Academic, 2019, p. 84.

7 I. GARCÍA DEL CORRAL, Cuerpo del derecho civil romano, Barcelona, 1889.

8 Digesto I, III, 22.

ISSN: 1133-0937

DOI: https://doi.org/10.20318/dyl.2021.5853
DERECHOS Y LIBERTADES

Número 44, Época II, enero 2021, pp. 167-208 
de la capacidad legislativa, no condicionada e inscrita en el imperio como elemento consustancial.

\section{EDAD MEDIA: EL DERECHO GODO-ESPAÑOL}

En la traducción del Digesto de García del Corral (1889), la 'indulgentia' romana fue traducida por la expresión 'perdón'. No es necesariamente lo mismo. El origen etimológico del término en latín es incierto, pero la traducción es significativa; consolida una entremezcla de categorías jurídicas clásicas con otras de la moral cristiana que fueron introducidas durante el Imperio romano tardío y continuaron presentes en el derecho godo medieval asimismo impregnado de la religión dominante. Su plasmación jurídica más significativa figura en el Liber Iudiciorum $(654)^{9}$, luego traducido al español en el Reino de Castilla para su aplicación en los juicios como Fuero Juzgo $(1241)^{10}$. La labor unificadora del derecho de Castilla fue continuada más tarde por Alfonso X con la promulgación de las Siete Partidas (1265). Tanto el Liber/Fuero como las Partidas recogieron disposiciones relativas a la amnistía -o figuras similares- generando marcos normativos abstractos que delimitaron por primera vez ese poder soberano tan extraordinario. Tres aspectos son relevantes de todos estos textos medievales a estos efectos dado que se relacionan dogmáticamente: la cuestión del origen del poder político máximo; sus límites; y la propia de la regulación de la amnistía.

\subsection{Liber Iudiciorum (654) y Fuero Juzgo (1241)}

Origen. El Liber/Fuero recoge en el Primus Titulus II una de las grandes cuestiones de la Teoría política señalada en el rótulo, "De electione principum"; cómo se escoge al primero en la pólis. Los reyes, en esta tradición, no reciben sus atribuciones públicas de Dios, ni del Emperador -al que igualan en poder en su territorio-, sino mediante un pacto social amplio: "cum conventu pontificum majorunque palatii vel populi omninmodo eligantur assen$s u^{\prime \prime}$. La misma regla, con ligeros matices, se recibe en el Fuero. De su lectura simple se extrae una conclusión: en el derecho español alto medieval y hasta el s. XIII, no hay asomo de forma divinizante de la traslación de los poderes

REAL ACADEMIA ESPAÑOLA, Fuero Juzgo en latín y castellano, Madrid, Ibarra, 1815.

10 A. IGLESIAS, La creación del Derecho. Una Historia del Derecho Español, 2, Barcelona, Signo, 1988, p. 260-262. 
máximos al Rey. La translatio iurisdictiones se sustancia a través de la aprobación ('assensu') de todas las fuerzas sociales concurrentes, obispos, aristócrates y pueblo. ¿Y qué pasaba cuando el rey moría? La regla VIII del Primer Titulo rechazaba el carácter hereditario de la summa potestas y fijaba condiciones para la elección del nuevo rey: debía ser del linaje de los godos "et fillo dalgo et noble, et digno de costumnes' y se volvía a la regla del "otorgamiento de los obispos, et de los godos mayores, et de todo el poblo". El pacto no era a perpetuidad, no creaba una suerte de derecho del soberano que trasladaba como propiedad, sino que debía ser renovado "quando el rey more" mediante otro proceso de elección que reflejara de nuevo la aceptación del candidato por todas las fuerzas sociales.

Límites. Ambos textos son fecundos también en la fijación de límites al poder máximo del Rey. En el Libro II Título I, II, emerge otra norma bajo el rótulo Quod tam regia potestas, quan et populorum universitas legum reverentiae sit subjecta, es decir, el Imperio del Derecho. El título en el Fuero es más breve aunque fiel al original "Que el rey é los pueblos deven ser sometidos a las leyes". El Nómos basileus griego. Este sí era en principio un mandato divino. En la versión del Fuero:

“Nuestro sennor ... manda guardar iustitia en la santa ley á todos ... damos leyes en semble pora nos, é pora nuestros sometidos á que obedezcamos nos, é todos los regyes que vinieren despues de nos, é tod el pueblo que es de nuestro regno generalmente".

Así en el derecho de los tiempos del "rey d'Espanna et de Francia", la potestad soberana, a) emanaba, de modo ascendente, del consentimiento clerical, aristocrático y popular; y b) el papel del Hacedor de todas las cosas en estas cuestiones no era investir al Rey de sus poderes sino ordenarle "guardar iustitia" en un sentido claro: obedecer él y hacer cumplir a otros las leyes del Reino.

Amnistía. Los mismos textos muestran una regulación de la amnistía novedosa y compleja. Se aleja de la impronta romana y permite ver su relación con la teoría política inspiradora. Determinan dos planos normativos de la figura, uno sustantivo y otro procedimental. Se configura en la Ley VI, De servanda Principibus potestate parcendi, Título I, Libro 6 del Liber-Fuero en Ley VII, Título I, Libro 6, De la piedad de los príncipes-. La traducción al castellano está otra vez trascendida por dogmas cristianos; sería más fiel De la potestad reservada a los Príncipes para ahorrar la pena: 
"Quando á nos ruegan por algun omne que es culpado de algun pecado contra nos, bien queremos oyr á los que nos ruegan, é guardamos por nuestro poder de aver les mercet. Mas si algun omne fizo algun malfecho contra muerte de rey ó contra la tierra, non queremos que ninguno nos ruegue por ellos. Mas si el princip los quiere aver mercet por su voluntad ó por Dios, fagalo con consejo de los sacerdotes é de los maiores de su corte".

Es evidente que este momento postromano vertebró una concepción de las amnistías diferenciable. La ley concedió al rey la potestad general de "culpas omittere" a los delincuentes por piedad, o de "aver merced", lo que, por su laxitud, podría significar tanto amnistiar, como indultar o conmutar penas, tanto por su propia iniciativa como de modo rogado. Tal capacidad de alguien de solicitar merced, gracia o perdón se perdía con respecto a los delitos más graves contra "gentis et patria" ${ }^{11}$, contra el 'pueblo' o la patria, lo que pasa a ser en el Fuero "malfecho contra muerte de rey o contra la tierra" 12. No siendo exactamente lo mismo, puesto que aquí el sujeto pasivo del acto delictivo pasa a ser la figura que ostenta la summa potestas, esta regla particular se refiere a delitos de lesa majestad como el regicidio, sedición, rebelión o similares que son referidos en el Libro II, I VI "De los que son rebelles, ó mal obedientes contral príncipe, ó contral pueblo, ó contra la tierra" ${ }^{13}$. Pero incluso ante estos graves delitos, si bien se perdía el derecho a solicitar el perdón o amnistía, el Rey, con el consejo ('adsensu') de los sacerdotes y de la corte, aún disponía de la potestad de liberarlos de sus castigos por su propia voluntad misericordiosa o ejerciendo la misericordia de Dios, factor este divinizante del poder regio. En cualquier caso, el Liber/Fuero indican que para estos graves delitos la aprobación de la omisión del castigo se debía hacer 'cum adsensu sacerdotum y maiorumque palatii'. Así las cosas, a diferencia del proceso de elección del Rey, para la concesión de amnistías relativas a los más graves delitos no se exigía la participación del tercer brazo social, el pueblo; sólo se previó la aceptación de los otros brazos. En todo caso, se afirma la idea de ciertos límites a la facultad regia, incluso cuando el Fuero diluye el 'adsensu' y lo transforma en mero 'consejo', lo que ofrecería más discreción al Rey en su decisión. Para el resto de delitos, el Liber/Fuero consideraba que su concesión

11 Códices de San Juan de los Reyes y San Isidro de Leon: "pro causa autem regix potestatis vel patrix",

12 Cód. Marqués de Malica 2 y Cód. Escorial 1, "muerte de nuestro linage ("ó de nuestro regno) ó de nuestra tierra".

13 En esta ley parece que el Rey sólo puede fijar pena alternativa a la ejecución del reo o su ceguera como el exilio. 
era una potestad regia plena, trasladada en el pacto social original que no se sometía a límites o condiciones. Estos textos contienen además otra regla interesante. Los reyes futuros no podían derogar las amnistías aprobadas por los reyes anteriores. Los castigos de los delitos contra la patria y contra el Rey, los castigos de las "pestilencias" de las que "sono avidas en la tierra de los godos é quantos aguijnamiehntos por la maldad, é por la sobervia daquellos que son rebelles" podían ser perdonados "mas aquellas personas son sacades desta ley á quien perdonáron los reyes, que fuéron ante nos" ${ }^{14}$. Aprobada una amnistía, la aplicación de la regla de no retroactividad de las normas punitivas y el principio de seguridad jurídica impedía a futuros soberanos derogarlas. Era otro límite material a la soberanía.

\subsection{Siete Partidas (1265)}

Hasta aquí, hay dos aspectos destacables del medievo en estos temas. Por una parte, la potestad de conceder gracia, indulgencia, merced, etc. por los crímenes cometidos se configura claramente como un poder reglado sustantiva y procedimentalmente. De otro, emanaba de dos fuentes teoréticamente diferenciables; su poder temporal es trasladado mediante pacto social con los aristócratas y el pueblo; y una porción de poder espiritual que se incorporaba al mismo pacto en la medida en que integraba la aceptación de esta manifestación de la summa potestas a la jerarquía católica -mecanismo conciliaristas-. La fórmula "quiere aver mercet por su voluntad ó por Dios" condensaba bien ambas legitimidades; presume una cierta posición espiritual del Rey similar a la de un Ministro de Dios en la tierra que ejerce misericordia para omitir penas temporales adjuntadas al delito. Esta fusión de planos de legitimación, extensiva del poder del soberano -próxima a las indulgencias del cristianismo primitivo- es reforzada y matizada en las Siete Partidas promulgadas por el Alfonso X el Sabio ${ }^{15}$. Su texto iniciaba un alejamiento de la summa potestas con respecto al pacto sin eliminarlo todavía.

Origen. Las Partidas aborda más sintéticamente que el Liber los mismos temas filosóficos incorporando en las reflexiones la teoría de las dos espadas del Papa Gelasio I (s. V). Es conocida la distinción platónica de Agustín en De Civitate Dei entre la 'civitas caelestis' y la 'civitas terrenal' siendo superior

14 Libro II, I VI in fine.

15 A. IGLESIA, La creación del Derecho. Una historia del Derecho español. Lecciones, Barcelona, 1991, p. 284 y ss. 
la primera sobre la segunda. Gelasio I en su Carta al Emperador de Oriente Anastasio I reformuló la idea aludiendo a las relaciones entre la espada temporal y la espada espiritual, ostentadas respectivamente por el Emperador y el Papa. Determinó la diarquía Papado-Imperio del medievo. Gelasio acepta un sometimiento de cada institución al otro en función de la materia, temporal o espiritual, sobre la que se proyecten decisiones ${ }^{16}$. Cuando analiza la auctoritas sacrata pontificum con respecto al príncipe, somete su voluntad al juicio papal y a la inversa con respecto a la regalis potestas temporal. De la doctrina gelasiana hay otro detalle. Indica que la potestad del Emperador "se te ha otorgado por la disposición divina". La carta ha dado lugar a múltiples debates sobre su sentido y alcance ${ }^{17}$. Interesa ver su impacto en las Partidas. Se percibe claramente en el prólogo a la Partida II en la que se busca concretar mejor la distinctio iurisdictionum entre el poder secular y la autoridad eclesiástica, rechazando cualquier superioridad papal en lo temporal como pretendía el papa de la época Gregorio VII:

"Los prelados de santa iglesia ... su poderio es espiritual, que es todo lleno de piedat... nuestro Señor Dios puso otro poder tenporal en la tierra... por mano de los enperadores et de los reyes. Et estas son las dos espadas... la una espiritual et la otra temporal, ca la espiritual taya los males ascondudos et la tenporal los manifiestos".

Esta visión conduce a una mayor divinización del poder regio y la correspondiente limitación del valor pacticio. Las dos teorías, la antigua contractual y la de legitimación divina conviven mal en la Partida Segunda, Título I, Ley I ${ }^{18}$. El poder regio, "á él pertenesce segunt derecho et el otorgamiento quel ficieron las gentes antiguamente de gobernar et de mantener el imperio", una suerte de origen remoto; pero a su vez lo ostenta como "vicario de Dios en el imperio para facer justicia en lo temporal". El texto trabó una síntesis peculiar de la doctrina teocrática gelasiana descendente -voluntad divina que pone

16 En latín en A. THIEL (Ed.), Epistolae Romanorum Pontificium Germinae, vol. 1, Braumbsverg, 1868, pp, 350-51. E. JONKERS, "Pope Gelasius and Civil Law", The Legal History Review, vol. 20 núm. 3, pp. 335-339; A. COTTRELL, "Auctoritas and Potestas: A Reevaluation of the correspondende of Gelasius I on Papal-Imperial relations", Medieval Studies, 55, 1993, pp. 95-109.

17 En especial por la Querella de las investiduras (s. XI). Enrique IV acusa al Gregorio VII de haber usurpado la espada temporal. La doctrina de Gelasio se recoge en Decreto de Graciano Prima Pars Dist. XCVI c. 6-10.

18 RAH, Las siete partidas del Rey don Alfonso el Sabio, Madrid, 1807, tres tomos.

DERECHOS Y LIBERTADES

Número 44, Época II, enero 2021, pp. 167-208
ISSN: 1133-0937

DOI: https://doi.org/10.20318/dyl.2021.5853 
un poder temporal-; con la godo-romana preimperial propia también de los decretalistas ${ }^{19}$ : pacto social ascendente remoto o no. $\mathrm{Y}$ ahora este poder le pertenece al Príncipe según derecho ${ }^{20}$. Esta concordia de cánones discordantes ${ }^{21}$ conduce a nuevos modos de traslación de la potestad a la muerte del Rey.

En la Ley IX, Partida II, se fijan las formas como "se gana el regno derechamente". Son cuatro. La primera y principal es la herencia de la summa potestas por los descendientes: "por heredamiendo hereda los regnos el fijo maior..." Solo subsidariamente, en ausencia de heredero legal, se vuelve al pacto "por aveniencia de todos", aunque también podrían regir otras reglas secundarias: el casamiento con heredera del reino; o el otorgamiento del Papa o Emperador. El antiguo contrato quedó relegado en el momento de sucesión del finado y concurría sólo como modo secundario o terciario de transferencia. La jurisdicción temporal se racionalizó como un derecho, de origen híbrido, fruto parte de la voluntad humana parte de la voluntad divina, y se traspasaba como heredad como si reflejara una voluntad de Dios permanente. Toda esta normativa marca un momento ecléctico de tránsito hacia el absolutismo. El rey a título de derecho transmitirá a sus descendientes la summa potestas sin obtener el beneplácito de los súbditos rompiendo el sistema electivo previo.

Límites. La Ley XI, Partida I, sí continúa la otra línea del Liber y somete esa honra al imperio del derecho:

"Todos los hombres deben ser tenudos de obedecer las leyes, et mayormente los reyes ...porque son por las leyes honrados et guardados...porque los ayudan á complir iustitia et derechos... porque ellos son facedores de ellas, et es derecho pues que las ellos facen, que ellos las obedezcan".

Así la obligación del príncipe es hacer justicia mandando que se cumplan las leyes: "Los reyes deben ser firmes en mandar complir la justícia" 22. Pero la sabiduría en el ejercicio de su jurisdicción hace que puedan y deban

19 HUGUCCIO, Summa decretorum (1181-1190): "el emperador recibe el poder de la espada...no de los obispos, sino de los príncipes y del pueblo, por elección, tal como leemos en el Decreto 93]". NANU, La Segunda... cit. p. 166.

20 Más perceptible en Alfonso X: Fuero Real (1255), Título II Ley II; y Espéculo (1255-60), Libro II, Leyes III y V. BOE, Fuero Real de Alfonso X el Sabio, Madrid, 2015; y Opúsculos del Rey Sabio, Madrid, 2018.

21 Desaparece en Ley V: "Vicarios de Dios son los reyes cada uno en su regno puesto sobre las gentes..."

22 Ley III, Tít. XXXII, Partida VII, in fine.

ISSN: 1133-0937

DOI: https://doi.org/10.20318/dyl.2021.5853
DERECHOS Y LIBERTADES

Número 44, Época II, enero 2021, pp. 167-208 
"usar a las vegadas destas tres bondades de misericordia, et de merced, et de gracia" ${ }^{23}$. Estas son las fuentes de su facultad de 'culpas omittere'.

Amnistía. Continuando la tradición del derecho godo, al Rey se le reconoce la potestad de hacer uso de distintos mecanismos de hacer merced para evitar consecuencias indeseadas de una aplicación rigurosa de la ley. A saber, en las Leyes L y LI, Título XVIII, Partida III; y en las Leyes I, II y III, Título XXXII, Partida VII. La Ley L se titula De las cartas de gracia que da el rey porque non venga daño en su tierra. La Ley LI hace mención a otras razones que pueden justificar su otorgación. La suma de ambas normas hace que al Rey le esté permitido otorgar amnistías (gracias, mercedes, etc.) por tres razones: a) "si la non ficiesen que se podrie tornar en daño"; b) "por merescimiento" y c) "por bondat". La primera justificación se incluiría hoy en el "interés general", lo que permite al Rey liberar de las penas de proscripción ("si hobiese echado de tierra á algunos") o de la cárcel a los que se encuentren en prisión ("ó toviese presos a algunos malfechores"). Y son también razones de orden político, en este caso, el "bien" que se haya hecho al reino o al Rey, ilustrativamente, prestándole servicios de armas ("acorriese al rey ó al regno en tiempo de guerra ó en otra sazon") lo que permite al Rey conceder gracia "por merescimiento". La 'bondat' sería aún otra forma de alcanzar la amnistía; simplemente su sentido ético natural de fomentar el bien o a evitar el daño de otros -v. gr. los familiares-.

Ciertamente, estos textos adolecen de ambigüedades terminológicas para distinguir 'piedad', 'perdón', 'merced', 'indulgencia', etc., palabras no fácilmente diferenciables. Pero es evidente que en esa potestad estaban contenidas las amnistías, en su sentido actual más riguroso, aunque no aparezca como tal. La distinción normativa entre lo que hoy son las figuras de la 'amnistía' y el 'indulto' se precisa en la Ley II del Título XXXII, Partida VII, puesto que perdonan á las vegadas los reyes á los homes las penas que les deben dar, bien ante que den la sentencia contra ellos, y los agraciados son quitos de la pena que debien recibir et cobrar su estado et bienes; o bien despues que fueron juzgados, siendo aquí el único efecto asegurado la inaplicación de la pena, puesto que los bienes, nin la honra nin la fama son aquí restaurados salvo si el perdón del rey se les extendiera ${ }^{24}$. Aún cabe resaltar otro matiz. Es el Rey quien perdona, amnistía, es indulgente, u otorga gracia liberado de evacuar aceptación o consejo de los que le prestaron su consentimiento para regir; los que mediante

23 Ibid.

24 En el Espéculo,.Libro II, Ley II; en Fuero Real I, 2. 
“otorgamiento" le "ficieron las gentes de gobernar" no participan en la decisión. La atribución de un origen divino al poder y el hecho de que la traslación ascendente se haya transformado en un 'derecho' a perpetuidad hace que la summa potestas se separe al completo del 'adsensu' de los gobernados en la concesión del perdón. Este 'derecho' se ha integrado en la soberanía que ejerce el rey sin límites externos.

\section{CONFLICTO Y AMNISTÍA EN LA EUROPA DE LOS SS. XVI Y XVII}

\subsection{Espíritu del siglo: bellum omnium contra omnes}

Además del conocimiento de este legado normativo, Las Casas y Grocio tenían frente a sí prácticas políticas de su tiempo ${ }^{25}$. Los ss. XVI y XVII precipitaron acontecimientos que sacudieron la Historia Universal. En el plano jurídico, de entre todos los cambios se debe hacer hincapié en la cristalización del Estado moderno en paralelo a la Reforma protestante. La idea del Estado soberano e independiente de tutelas externas se alumbra en Europa como una forma de eliminar cualquier sometimiento al Papado y al Imperio de los que ostentaban formas de potestas subordinadas, e incluso de la sumisión de la potestas imperial a la auctoritas papal. En añadido la Reforma separaba también a los fieles de la tutela católica de la Iglesia de Roma en favor de una relación directa e inmediata entre el príncipe y Dios o el cristiano y Dios. Estas tendencias hicieron emerger gradualmente un nuevo modelo de relaciones de los cuerpos político-espirituales entre sí y del Estado emergente con el cuerpo social sobre el que se proyectaba la potestas o el imperium. El Príncipe (1513) de Maquiavelo ofrece una buena idea de cuáles eran los problemas que angustiaban al gobierno de la República de Florencia, extrapolables mutatis mutandi al resto de máximas autoridades de los poderes temporales emergentes con el desvanecimiento progresivo del sistema político carolingio. Condensa los consejos prácticos de Maquiavelo a Lorenzo II de Medici para gobernar y conservar el poder frente a las sediciones internas en una época caracterizada por la lucha de la república florentina contra las trabas que los modos feudales imponían a la consolidación de un Estado más fuerte, y frente a los ataques de los Estados italianos circundantes, recomendando veladamente la implicación del Papa en la conquista de Italia por

25 V.gr. Las Casas cita las Siete Partidas, en De regia potestate I, III, 1-3; II, XV, 1; III, XXVI, 2-3. 
los Medici ${ }^{26}$. Todo se cuestiona así. Reyes y Emperador niegan su subordinación al Papa en cuestiones temporales ${ }^{27}$ e incluso, en ciertos casos, como Inglaterra, la propiamente espiritual; los poderes más locales, tanto laicos como religiosos -condados, marquesados, etc.- discuten la figura del Rey que quiere ejercer en un territorio que abarca estos poderes menores una summa potestas equiparable a la del Emperador, o la del mismo Papa cada vez menos conciliar ${ }^{28}$; e incluso el sometimiento del pueblo al dominio de los privilegiados ${ }^{29}$. La soberanía e independencia del Estado fue la respuesta final hacia el interior y hacia el exterior que resolvía el marasmo general; se alcanzó mediante el espectáculo del bellum omnium contra omnes del final de la cristiandad medieval mencionado por Hegel ${ }^{30}$.

\section{AMNISTÍAS, INDULTOS, PERDONES, NACIONALES E INTERNACIONALES}

Este ambiente de hostilidades sin fin creó el contexto propicio para la aprobación de amnistías y perdones de derecho interno e internacional en el conjunto de Europa. De hecho, con frecuencia las guerras incesantes se interrumpían con la aprobación de 'perdones' o 'amnistías' con uno u otro alcance. Cuando la amnistía se concluyó tras una guerra internacional, fueron actos normativos internacionales, celebrados entre soberanos, los que las alumbraron. Si la amnistía sellaba una rebelión eran actos normativos internos los que la promulgaban. Así, la amnistía se convirtió otra vez en una institución fundamental del sistema jurídico europeo, nacional e internacional, como lo fue en su momento en el violento mundo de Estados-Ciudad soberanos e

26 MAQUIAVELO, El Príncipe, M. E. Editores, 1994, p. 37.

27 El Emperador Carlos V, que de conformidad con las formas gelasianas medievales debía ejercer como brazo armado en lo terrenal de la cristiandad, asesta un mazazo a la utopía carolingia con el saqueo de Roma de 1527 por las tropas imperiales. Sobre el saco de Roma por las tropas imperiales, J. BONAPARTE, Le sac de Rome, Imprimerie Granducale, Florence 1830.

28 Tras el saqueo de Roma, el cardenal Colonna, adversario de Clemente VII, entró en la Ciudad Vaticana con un ejército para ajustar sus cuentas con el Papa. M. FERNÁNDEZ, Sombras y luces de la España Imperial, Espasa, 2004, pp. 36-37.

29 La rebelión más célebre es la Guerra de los campesinos alemanes (1524-1525) o ‘Erhebung des gemeinen Mannes'. P. BLICKLE, Der Bauernkrieg. Die Revolution des Gemeinen Mannes, Berlin, C.H. Beck, 1998; M. HUGHES, Early Modern Germany: 1477-1806, Macmillan, London, 1992; FR. ENGELS, Der deutsche Bauernkrieg, Hamburg 1850.

30 G. W. F. HEGEL, Lecciones sobre la filosofía de la Historia Universal (1830), Alianza Editorial, Madrid 2001, p. 610. 
independientes griegos, un derecho que tuvo por objeto principal en aquella época la facilitación de una paz duradera que pusiera fin al estado de guerra continua que acompañó el advenimiento de los Estados modernos para satisfacer las ambiciones particulares de grandeza que acompañaron a cada una de ellos.

\subsection{Perdón General de Valladolid (1522): gracia a los comuneros}

Los reyes españoles no dudaron en hacer uso de la potestad de conceder perdón reconocida en el Fuero o en las Partidas cuando lo creyeron aconsejable. Muestran siempre una naturaleza discrecional y selectiva en su otorgamiento. En España, entre los más notorios figuraría el Perdón general promulgado en Valladolid el 1 de noviembre de 1522 por Emperador Carlos V (Carlos I de España) con el fin de evitar el castigo de los participantes en la Guerra de los comuneros (1520-1522) ${ }^{31}$.

La Guerra de las Comunidades de Castilla se origina con la rebelión de los comuneros en 1520 al poco del inicio del reinado de Carlos I de España. Carlos I viaja desde Flandes -donde ha nacido y ha sido educado- hasta España para tomar posesión de su corona acompañado de su corte flamenca y borgoñesa. En 1517 abre las Cortes de Valladolid para reclamar su título de Rey de Castilla y León sin apenas hablar castellano. Aunque jura los fueros y es aceptado como Rey, su corte europea suscita recelos entre nobles y clérigos castellanos, temerosos de perder su influencia en los asuntos del reino ${ }^{32}$. Estos factores, sumados al presunto expolio de las riquezas nacionales atribuido a la nueva corte extranjera, causan las revueltas en distintas ciudades castellanas que propugnaban a Juana la Loca como titular del trono castellano en sustitución de su hijo. Los mitificados Padilla, Bravo, o Maldonado, y sus seguidores, lucharon contra las tropas imperiales y acabaron derrotados en 1522. Carlos I adoptó entonces el Perdón general para los que habían participado en la revuelta comunera aun habiendo cometido crímenes de lesa majestad -sedición y traición-. La amnistía contenía, sin embargo, un listado de 293 personas - pertenecientes a todas las clases sociales y en las que se incluyó al Obispo Acuña- que fueron excluidos de la gracia ${ }^{33}$. Sobre esta am-

31 En general, J. A. MARAVALL, Las Comunidades de Castilla, Alianza Editorial, 1979.

32 M. FERNÁNDEZ, El Imperio de Carlos V, Madrid, Real Academia de la Historia, 2001.

33 La lista de personas que no fueron amnistiadas el 1 de noviembre de 1522 por el Perdón General de Valladolid puede consultarse en. http://www.cervantesvirtual.com/bib/historia/CarlosV/7_1_31.shtml. 
nistía o Perdón general la Enciclopedia moderna de España indica que sus efectos alcanzaron la concesión del perdón "a los que se hallaban procesados o encarcelados" e incluso "anuló las causas no sentenciadas" y mandó reponerles en "su buena reputación y fama, devolviéndoles los bienes que tenían por tales motivos confiscados" ${ }^{34}$. El Rey, aplicó así su prerrogativa de amnistiar y perdonar fijada en las Partidas.

\subsection{Tratado de Câteau-Cambresis (1559)}

Del s. XVI llegan a su vez varios tratados relevantes en los que la paz entre soberanos se construye sobre el olvido perfecto de los crímenes pasados. De hecho, lo hallamos en el tratado más importante de la época en el continente europeo, el Tratado de Câteau-Cambresis entre Francia y España, de 3 abril de 1559, con el que se pone fin a la última de las Guerras de Italia (1551$1559)^{35}$. En su primera disposición incorpora el compromiso de paz perpetua entre los reinos de Francia y España junto a una cláusula general de amnistía entre los cristianísimos reyes y sus descendientes: "oubliant toutes choses ci-devant mal passées, quelles qu'elles soient qui demeureronot abolies \& éteintes". Más interesante incluso que la amplia cláusula son las disposiciones particulares, con uno u otro contenido y alcance, que ofrecen concreción. Los firmantes asumen la obligación de no perseguir a sus súbditos por haber tomado parte en la guerra contra su propio soberano. Se trata de lograr que los habitantes de este o aquel territorio que se hubieran decantado por el bando contrario al que acaba siendo su soberano al finalizar la guerra pudieran recuperar íntegramente sus derechos y propiedades previos a la contienda y gozaran de garantías de no persecución futura por su traición. Así con respecto a los "gentilhombres de Siena y otros Sujetos de dicho Estado" que decidan volver a su tierra "y seront reçûs, \& leur sera pardonné tout ce que l'on pourroit pretendre à l'encontre d'eux... et leursdits biens avoient été pris \& saisis, leur seront rendut \& restituez, poir en jouïr pleinement." ${ }^{36}$ La estructura del tratado explica el modo espiritual, político y jurídico de la época: se pacta

34 Los literales proceden de la voz "amnistía" de la Enciclopedia Moderna de España, op. cit. Vol. II, pp. 382-384.

35 Tratado de Paz entre Enrique II, Rey de Francia, y Felipe II, Rey de España (CâteauCambresis), de 3 de abril de 1559. J. DU MONT, Corps Universel Diplomatique du Droit des Gens, Tome V. Partie I, Amsterdam, 1728, p. 30 y 34-44. Sobre el tratado B. HAAND, Une Paix pour l'éternité, Casa de Velázquez, Madrid, 2009.

36 Cláusula 35, DU MONT, Corps Universel ... cit., p. 38.

DERECHOS Y LIBERTADES

Número 44, Época II, enero 2021, pp. 167-208
ISSN: 1133-0937

DOI: https://doi.org/10.20318/dyl.2021.5853 
una paz perpetua; cesan las hostilidades entre soberanos por las causas esgrimidas para iniciarlas; se amnistían y olvidan aquellas causas y todas sus consecuencias, para evitar que se vuelvan a convertir en motivo de discordia; incluso se fijan amnistías para los propios súbditos si se alzaron en armas contra el soberano en favor del adversario; se redistribuyen soberanías; y para una "mayor confirmación de esta paz y para hacer la amistad, confederación y unión más firme e indisoluble", se pacta un matrimonio regio, la hija mayor del Rey de Francia, se casará con el Rey Felipe II de España.

\subsection{Edicto Perpetuo (1577)}

De esta época llega también un tratado internacional atípico, el acuerdo de Pacificación de Gante celebrado entre todas las provincias de Flandes el 8 de noviembre de 1576 y después firmado por Juan de Austria en representación de Felipe II de España y por los Estados generales de Flandes, el 7 de enero de 1577, mediante el Edicto Perpetuo (o Tratado de Marche-en-Famenne). El acuerdo es uno de los primeros intentos de paz en la Guerra de Flandes iniciada en 1568 que conduciría finalmente a la secesión de las provincias holandesas de la Corona de España reconocida en la Paz de Westfalia (1648). La Pacificación de Gante (1576) y su ratificación con el Edicto perpetuo mantenía el reconocimiento de Felipe II como Rey de las provincias holandesas rebeldes -de ahí que la naturaleza de este tratado sea parecida a la de los acuerdos híbridos actuales que se celebran entre las partes de una guerra interna-; ordenaba el respeto al catolicismo en las provincias rebeldes; pactaba el retiro de los Tercios del territorio flamenco; ambas partes renunciaban además a toda alianza contraria al Edicto; y en su Art. I, pórtico de entrada a todo lo acordado, ordenaba una amnistía absoluta:

"Primero, que todos los delitos, calumnias, fechorías y daños que ocurran como resultado de los problemas entre los habitantes de las provincias incluidas en este tratado, sin importar dónde o cómo ocurrieron, serán perdonados, olvidados y considerados como no ocurridos, para que nunca se haga mención de ellos y nadie sea demandado por ellos" ${ }^{37}$.

No habría reclamaciones judiciales, se olvidaría públicamente todo lo sucedido, como si hasta la historia debiera omitir las barbaridades ocurridas y el perdón cristiano cubriría los huecos morales.

37 En http://www1.umassd.edu/euro/resources/netherlands/17.pdf, 1 de febrero de 2016, traducción propia. 


\section{LA QUAESTIO DE IMPERATORIA VEL REGIA POTESTATE (1571) DE BARTOLOMÉ DE LAS CASAS}

La Discusión sobre la potestad regia e imperial de Bartolomé de las Casas, Quaestio de Imperatoria o De regia potestate 38 (póstuma, 1571) contiene la primera reflexión general de la época que cuestionaba y condicionaba la validez jurídica de la figura de la amnistía. El opúsculo, como tal, no tiene como finalidad ofrecer una forma de validación jurídico-moral de las amnistías, ni en concreto ni en general. De regia potestate es un escrito de Las Casas en el que, como en otros previos, se aborda la cuestión de la nulidad de las encomiendas en las Américas. Siendo este el objetivo instrumental del escrito, lo más fascinante del escrito es la teoría política, filosófica y jurídica general que sustenta su posición. Sorprende todavía la radical modernidad de los conceptos propuestos sobre múltiples aspectos relativos a la legitimidad del ejercicio de poderes soberanos y sus límites en el derecho natural y divino. Además, en la primera parte general (Cuestiones), a modo ilustrativo, como un obiter dicta, Las Casas se interroga sobre la validez y efectos de las amnistías. ¿Puede disponer el soberano de los derechos de los que son titulares sus súbditos a través de una amnistía?

Las Casas es uno de los precursores -quizá el más influyente de este siglo en esta materia- de la teoría de las libertades naturales del individuo y del pacto social como modo de configurar legítimamente las relaciones entre el individuo y el Estado. "Ningún Estado, ni Rey, ni Emperador puede enajenar territorios ni cambiar su régimen político sin el consentimiento expreso de sus habitantes", afirma las Casas. De regia potestate es el primer tratado moderno de filosofía política y derecho que asienta el principio democrático

38 En latín con traducción al castellano, L. Pereña, B. DE LAS CASAS, De regia potestate, CSIC, Madrid, 1969. En general A. ROSILLO, La tradición hispanoamericana de derechos humanos, Corte Constitucional del Ecuador, Quito, 2012, pp. 59-222; M. BEUCHOT, Los fundamentos de los derechos humanos en Bartolomé de las Casas, Anthropos, Barcelona, 1994; R. I. PEÑA, "La teoría teocrática de Fray Bartolomé de las Casas O.P. y el regnum indiarum, Estudios en honor de Alamiro de Ávila Martel", AUCh, núm. 20, 1989, pp. 401-424; L. HANKE, La lucha por la justicia en la conquista de América, Istmo Colombia, Madrid, 1988, pp. 405-419; K. J. PENNINGTON, "Bartolomé de Las Casas and the Tradition of Medieval Law", Church History, vol. 3, núm. 2, 1970, pp. 149-161; L. PEREÑA, "Estudio preliminar", en LAS CASAS, De regia... cit. pp. xxi-clvii; L. HANKE, Bartolomé de las Casas, an interpretation of his life and writings, Springer, 1951; T. URDÁNOZ, "Las Casas y Francisco de Vitoria en el V Centenario del nacimiento de Bartolomé de las Casas 1474-1974" en L. HANKE, Las teorías políticas de Bartolomé de Las Casas, Univ. de Buenos Aires, 1935, pp. 115-191.

DERECHOS Y LIBERTADES

ISSN: $1133-0937$

Número 44, Época II, enero 2021, pp. 167-208

DOI: https://doi.org/10.20318/dyl.2021.5853 
del derecho de autodeterminación de los individuos, el pacto social como consecuencia de su ejercicio, y el Imperio del Derecho como mecanismo de protección frente a los abusos de quien ejerza poderes soberanos.

\subsection{Contra las 'encomiendas'}

Las Casas combatió en múltiples escritos el régimen jurídico de las 'encomiendas' que se había aplicado a la expansión de la corona española en las Indias occidentales desde $1499^{39}$. Los elementos básicos de esta figura jurídica guardaban relación con ciertas formas normativas feudales españolas en retroceso en la España moderna del s. XVI. La Corona "encomendaba" a los indios americanos y a sus tierras, esto es, los colocaba a cura de los conquistadores destacados que se convertían así en 'encomenderos'. La encomienda creaba un régimen de derechos y obligaciones entre tres sujetos, 'encomenderos', 'encomendados' y Rey ${ }^{40}$. Los encomenderos disponían de la competencia para exigir en su favor prestaciones (trabajos remunerados o tributos) de los 'encomendados', a cambio de su obligación de cristianizarlos y protegerlos de forma benevolente ${ }^{41}$. A su vez los 'encomenderos' asumían la obligación de defender la soberanía del Rey en América y de enviar los tributos correspondientes a la Corona. En la práctica el régimen, por su propia naturaleza inicua, no tardó en degradarse hasta caer en formas encubiertas de esclavitud o servidumbre forzosa ${ }^{42}$. La primera denuncia de este régimen se hizo desde el púlpito de la Isla Española por el dominico Montesinos $(1511)^{43}$. Acusó a los conquistadores de vivir en "pecado mortal" por tratar con tiranía y crueldad a los indios. Como reacción a la denuncia Fernando II aprobó las Leyes de Burgos u Ordenanzas para el tratamiento de los indios (1512). No prohibió con ellas la encomienda pero se reconocieron a los indios su

39 Primera denuncia en Memorial de remedios para las indias de 1516 y de 1518, Fr. BARTOLOMÉ DE LAS CASAS, Obras escogidas de Fray Bartolomé de las Casas, V, Tomo CX, BAE, Madrid, 1958, pp. 6-27; y 31-35.

40 El inicio de este régimen se atribuye al propio Colón en 1498 en La Española, J. CHEZ CHECO, "El sistema de encomiendas en Santo Domingo durante el siglo XVI”, CLÍO 71, vol.165, 2003, p. 67.

41 E. RODRÍGUEZ DEMORIZI, Los Dominicos y las encomiendas de Indios de la Isla Española, Santo Domingo, Academia Dominicana de la Historia, 1971, pp. 25-26.

42 Así había pasado también en el mundo germánco medieval, G. BELOW, Der Deutsche Staat des Mittelalters. Eine Grundlegung der deutschen Verfassungsgeschichte. 1. Die allgemeien Fragen, Leipzig, 1925.

43 ROSILLO, La tradición..., cit. pp. 108-113; T. URDÁNOZ, “Las Casas...”, cit. p. 118.

ISSN: 1133-0937

DOI: https://doi.org/10.20318/dyl.2021.5853
DERECHOS Y LIBERTADES

Número 44, Época II, enero 2021, pp. 167-208 
condición de hombres libres, súbditos del rey, y con ello sus derechos a la propiedad de sus casas y tierras. Aunque se establecía también que se les podía obligar a trabajar, las Leyes de Burgos les reconocía el derecho a un trabajo tolerable y con descanso y a la remuneración justa que les garantice la holgura para ser instruidos en la fe. La ley fue completada al poco con las Leyes de Valladolid (1513) que ampliaron el alcance de estos derechos laborales. Luego la Ley de heredad (1536) y la Ley de donaciones (1537) de las encomiendas, aprobadas por Carlos I, mantuvieron su existencia y determinaron que se podían trasmitir en herencia del finado o como dote en el casamiento de hijo o hija. Las Casas propuso entonces al Emperador la nulidad de las encomiendas en su Octavo remedio (1542) ${ }^{44}$. Aún sin lograr completamente el objetivo último, su posición inspiró la promulgación el mismo año de las Leyes y ordenanzas nuevas hechas por su Magestad para la gobernación de las Indias y buen tratamiento y conservación de los Indios (1542). Estas Leyes Nuevas (1542) prohibieron la concesión de nuevas encomiendas y desestimaron la perpetuidad de las existentes que terminarían a la muerte de sus titulares, aunque más tarde se permitirían excepciones a esta norma. Los fundamentos políticos, jurídicos y teológicos lascasianos para promover su nulidad son los mismos que fundamentaron su posición sobre la validez y límites de las amnistías.

\subsection{Libertad natural y pacto social}

Hay una teoría político-moral amplia en Las Casas ${ }^{45}$. Parte de una premisa antiaristotélica. El párrafo I de De regia potestate efectúa la siguiente afirmación:

"Desde el principio del género humano, todos los hombres, todas las tierras y todas las otras cosas, por derecho natural y de gentes, fueron libres y alodiales, o sea francas y no sujetas a servidumbre." 46

Es el eje ontológico de otros escritos previos y se inspiraba en el derecho romano ${ }^{47}$. En De unico vocationis modo (1537) concede a todos, por el hecho de

$44 \quad$ BAE, Madrid, 1958, cit., p. 70.

45 Ese marco teórico se había expuesto con menos detalle en escritos previos. Vide Principia quaedam (1552) en De regia potestate, op. cit. p. 140. El mismo volumen recoge este y otros escritos de Las Casas; también en B. DE LAS CASAS, Tratado comprobatorio del Imperio Soberano, Sevilla 1552, p. 63 (copia digital de la Biblioteca de Andalucía).

46 LAS CASAS, Apologetica historia sumariae, vol. I, Alianza Editorial, 1992, p. 461.

$47 \quad$ Institut. Liber Primus, Tit. II, § 2. "por derecho natural todos los hombres al principio nacían libres".

DERECHOS Y LIBERTADES

ISSN: 1133-0937

Número 44, Época II, enero 2021, pp. 167-208

DOI: https://doi.org/10.20318/dyl.2021.5853 
pertenecer a la raza humana, el derecho a no ser privados arbitrariamente de su libertad, de sus posesiones o de sus propiedades, lo que volvía nula su esclavitud o su conversión forzosa a la Fe Cristiana ${ }^{48}$. Los indios pertenecían en pie de igualdad al género humano y con ello gozaban de sus mismas libertades naturales. En la razón Nona del Octavo remedio afirma que "todos aquello pueblos y gentes son libres, y que a nadie del mundo debían nada antes que se hallasen ni cuando se hallaron, ni hoy deben después de hallados sino a Vuestra Majestad servicio y obediencia (...) como la que deben los pueblos y ciudades libres a su universal rey y señor" ${ }^{49}$ Hobbesiano o roussoniano, lo esencial del estado de naturaleza para Las Casas es que el generis humana, de conformidad con el iure naturae et gentium, nacieron libres e iguales - por su igual naturaleza libre- y, por ello, no sometidos a la voluntad de otros seres humanos. Remacha, "el hombre es libre, mientras no se demuestre lo contrario...en caso de duda hay que decidir en favor de la voluntad". La libertad es propia y connatural al hombre, está ínsita en su naturaleza, es un corolario irrenunciable de su ser humano, y por ello toda esclavitud es accidental. Así, la siguiente pregunta lascasiana a resolver era cómo puede un hombre libre válidamente limitar sus libertades originales.

En la Cuestión Segunda, párrafo IV de De regia potestate designa al consentimiento (voluntariae consentiret) como único modo válido de constituir sujeciones o servidumbres de esa libertad, y de constituir omnis auctoritas, potestas et iurisdictio del rey. Imperium immediate processit a populo, indica, et populus fuit causa efectiva regum seu principum si iustum habuerunt. A lo que añade otro corolario, cuando un pueblo eligió sus príncipes o sus reyes:

"no perdió su propia libertad ni renunció o concedió poder de gravarle, coaccionarle, ordenar o imponerle cargas en perjuicio de todo el pueblo o comunidad política...el pueblo ordenó o decretó los derechos del Rey...por esta razón en todos los negocios públicos se ha de pedir el consentimiento de todos los hombres libres" 50 .

Esta traslación tenía, por tanto, otro atributo lascasiano distintivo: las personas no perdían, tras ese pacto original traslaticio, sus libertades naturales.

48 L. HANKE, Bartolomé de Las Casas. An Interpretation of his Life and Writings, SpringuerScience, 1951, p. 40. Más en detalle, HANKE, Las teorías politicas de Bartolome de Las Casas, Universidad de Buenos Aires, 1935.

49 BAE, Madrid, 1958, cit. p. 94.

50 De regia potestate, cit. pp. 32-34. 
Esta sección vislumbra toda una modernidad occidental posterior ${ }^{51}$ que está presente, con matices, en otros autores de la Neoescolástica española como Fr. Suárez ${ }^{52}$-no realmente Fr. de Vitoria- ${ }^{53}$. Se recuperaba así, y sofisticaba, la anterior teoría romana ${ }^{54}$ y medieval de la traslación ascendente de la summa potestas - presente en el Liber/Fuero y algo más diluida en las Partidas- ${ }^{55}$, enriqueciéndola en sus fundamentos y efectos. Las Casas afirma que el origen justo e inmediato de las potestades que ejerce el soberano, es decir, el único válido en respeto de las libertades naturales de todo individuo, no se encuentra en la voluntad de Dios, como se vislumbraba en las Partidas, sino en la voluntad de los hombres titulares de libertades individuales, que mediante su consentimiento podían acordar el traslado de las facultades y derechos propios de su libertad individual a una institución. Además, la finalidad de esa transferencia, para Las Casas, era la salvaguarda del bien común. La potestas ac iursidiction regum "se aplica exclusivamente a promover los intereses colectivos del pueblo, sin poner estorbos ni perjudicar a su libertad." 56 Todas estas ideas perduraron hasta sus últimos escritos. Incluso se radicalizaron con el tiempo ${ }^{57}$.

\subsection{Nulidad y validez de las amnistías fijadas en Tratados de paz}

¿Hasta dónde alcanzaba entonces ese poder terrenal cedido conforme al pacto original constituyente? O de otro modo, ¿hasta dónde podía renunciar el titular de la soberanía libérrimamente a los derechos o libertades naturales

51 J. A. CÁRDENAS, "Consent, Voluntary Jurisdiction and Native Politic Agency in Bartolomé de Las Casas' Final Writtings, Bulletin of Spanish Studies, vol. XCI, núm. 6, 2014, pp. 793-817. En De Thesauris in Peru (1563) (Los Tesoros del Perú), uno de sus últimos tratados, insiste con vigor en la idea del consentimiento explícito como único modo, Vid. LAS CASAS, Los tesoros del Perú, A. Lozada (trad.), Madrid, CSIC., 1958 con edición facsímil del original, en especial sobre el libre consentimiento, pp. 269-271.

52 Fr. SUÁREZ en Tractatus de legibus ac Deo legislatore (1612), trad. J. Torrubiano, Tomo III, Madrid, 1918, Libro Tercero, Cap. II 164-II, 165-I, 165-II; y Cap. III y IV.

53 En De potestate civile (1528) afirma el origen divino de la potestad, Fr. VITORIA, Relecciones Teológicas, trad. J. Torrubiano Ripoll, Tomo II, Madrid, 1917, pp. 2-15.

54 Digesto Primer proemio § 7; Digesto I IV 1; Digesto I, II, 8; Digesto 43, 29, 1; Instituta II, 1,10 .

55 Desarrollada antes en la Escuela de Bolonia por Bulgarus, Azzo, Hugolinus, Odofredo y el radical Manegold de Lautenbach, Ad Gebehardum liber (1085) y Opusculum contra Wolfelmum coloniensem (1080). Un resumen, I. NANU, La Segunda Partida de Alfonso X el Sabio y la tradición de los Specula Principum, Tesis, Valencia, 2013, pp. 182-183.

56 De regia potestate... cit. Cuestión Segunda, Párrafo V.

57 J. A. CÁRDENAS, “Consent, Voluntary Jurisdiction...”, cit. pp. 793-817.

DERECHOS Y LIBERTADES

ISSN: 1133-0937

Número 44, Época II, enero 2021, pp. 167-208

DOI: https://doi.org/10.20318/dyl.2021.5853 
de sus súbditos por medio de un tratado celebrado con otro soberano? Dado que para fray Bartolomé el rey no ostenta en propiedad los territorios sobre los que gobierna, sino que únicamente ejerce sobre ellos las potestades o jurisdicción atribuida por el pacto social, según el protector de los Indios no quedó dentro de su competencia la posibilidad de disponer libremente las propiedades de los súbditos.

La Cuestión II Párrafo III sobre el Derecho de los reyes en cuanto a las tierras propias de personas particulares inicia este razonamiento fundamental para la evolución de la concepción de la soberanía a futuro. Las Casas determina el derecho a la propiedad como parte de esos derechos o libertades fundamentales originales de cada individuo no transferidos a la summa potestas:

"nada hay tan contrario a la equidad natural como verse obligado el dueño, sin consentimiento suyo, a perder violentamente lo que le es propio, cayendo de modo ilícito bajo dominio ajeno... ni los reyes ni los emperadores tienen poder fundado sobre las haciendas de los ciudadanos... ni tampoco dominio útil ni directo de los habitantes ... una cosa es la propiedad y otra muy distinta la jurisdicción...no importa que digan los reyes que el reino es suyo, pues ha de entenderse unicamente en lo relativo a la jurisdicción y a la protección del reino".

Ni la propiedad es jurisdicción, ni la jurisdicción es propiedad. Los súbditos sólo concedieron mediante el pacto original la jurisdicción. Por ello, si los reyes, emperadores $u$ otras formas soberanas no tienen dominio directo ni útil sobre las propiedades de los particulares, eran nulos los trasiegos de territorios, tan frecuentes en los tratados de paz como lo era de forma encubierta en las encomiendas, si no mediaba el consentimiento del pueblo afectado por esta circunstancia:

"Ningún rey o príncipe, por soberano que sea, puede legítimamente por donación, venta, permuta o cualquier otro modo de enajenación, ceder ciudades, villas, castillos... a menos que consientan libremente en esta enajenación los súbditos, vecinos o residentes de tal ciudad, villa o comarca. Y si lo hace el rey de hecho contra la voluntad o forzando el consentimiento peca mortalmente y no tiene absolutamente validez jurídica tal enajenación, negociación o sometimiento". (Conclusión II pár. XII-XXIII).

Y la conclusión ad minus que aquí nos trae es que tampoco los soberanos puedan disponer mediante de los derechos de reparación que corresponden a sus súbditos como consecuencia de los daños que la guerra haya causado en sus derechos y libertades naturales: 
"Es doctrina común que si el gobernante, Emperador, rey o pueblo que conserva los derechos de soberanía, pacta con los enemigos acordando que los ciudadanos no puedan reclamar indemnización por los daños ocasionados, tal acuerdo no tiene validez ni puede ser perjudicial a los ciudadanos". (Conclusión II pár. XI 3)

Así, las cláusulas de amnistía que figuraban en los tratados internacionales, que como muestra este obiter dicta conocía bien Las Casas, eran nulas, en general, y no vincularían a los súbditos porque "sería absurdo que el gobernante por razón de su renuncia privara de sus derechos a los ciudadanos". A lo que cabría sólo oponer la misma excepción que emerge de su teoría política general en el resto de supuestos analizados:

"Por más soberano que sea, no tiene el gobernante potestad para donar, conceder, permutar o negociar con bienes o daños de los súbditos sin haber requerido y obtenido legalmente su consentimiento expreso". (Conclusión II pár. I 1)

Extrapolando las ideas de De Thesauris in Peru, la consecuencia de esa nulidad si no hubiera mediado consentimiento expreso sería la obtención de las restituciones e indemnizaciones correspondiente a los particulares que habían sido hurtadas por la amnistía ${ }^{58}$. Las Casas, como se ve, otorga aún más peso que el que se concedió en el Liber/Fuero a la teoría del consentimiento puesto que en el derecho godo se entendía incluido en el pacto original ascendente la capacidad regia de conceder amnistías o perdones, salvo en los casos de los delitos contra 'gentis et patria'. E incluso en este caso era posible su concesión sin volver a recabar la aceptación del pueblo; bastaba con el adsensu de los brazos aristocrático y eclesiástico. Las Casas, con la introducción novedosa de su idea de las libertades naturales y el pacto social, trabó una formulación bajo control del pueblo del alcance de la jurisdicción concedida.

58 Así, en De Thesauris in Peru, tras la determinación de la nulidad de todos los títulos exhibibles por el Rey de España y los conquistadores, para ejercer la soberanía sobre el Perú, al situarse al margen de la Bula y no haber consentimiento válido, implicaba la obligación de restitución de todo, tierras y bienes, que habían sido hurtados o robados a los indios. Los Tesoros, cit. p. 35, pp. 368-69. 


\section{GROCIO: TEORÍA DEL ‘DOMINIO EMINENTE’}

\subsection{Protestantismo, derecho divino y absolutismo}

En la misma época, en sentido opuesto a la doctrina de la Escuela Española, Lutero facilitó el afianzamiento dentro del pensamiento occidental de la Filosofía política también presente en el derecho romano y medieval: el derecho divino como origen de la soberanía encarnada por el príncipe. Legitimó por vías teológicas el pensamiento absolutista en el occidente cristiano que sería abrazado por el excomulgado Enrique VIII de Inglaterra (1491-1547) o por el ya anglicano Jacobo I de Inglaterra (1566-1625) -aunque también por el siempre católico Luis XIV de Francia (16431715)- Su pensamiento político-teológico vaciaba a los individuos de sus libertades naturales básicas en el orden temporal potenciándolas en el más vago orden espiritual ${ }^{59}$. Resumo su teoría política: a) Los poderes ostentados por el Príncipe tienen un origen divino. Particularmente citado por Lutero es el enérgico pasaje de Pablo, Romanos 13.1-2 ${ }^{60}$, donde se afirma el deber cristiano de obedecer a las autoridades constituidas no imponiendo obstáculos ${ }^{61}$; b) sólo Dios puede juzgar al Príncipe y cualquier intento de restringir sus poderes es una herejía, opuesta a la voluntad divina; c) De ahí emerge la sumisión pasiva del cristiano a la autoridad del príncipe, incluso si la autoridad es mala o injusta. La libertad del cristiano, aclara Lutero, es espiritual ${ }^{62}$ y no puede confundirse con la liberación social y política. Por ello, en lo relativo a la autoridad temporal ordena a los cristianos a "ser pacíficos en estos asuntos, sufrir, y quejarse sólo ante Dios" ${ }^{63}$. Sufrir el mal es prueba de la Fe, "no hay que resistir al mal sino sufrirlo..." 64 .

La implantación de estas ideas arrumbaba el modelo medieval de la soberanía temporal limitada por leyes externas -de derecho divino o de derecho natural- que

59 ABELLÁN, J. Martín Lutero sobre la autoridad secular, Cuadernos de Historia Moderna 43 (2), 2018, pp. 337-345.

60 "Sométase toda persona a las autoridades superiores; porque no hay autoridad sino de parte de Dios, y las que hay, por Dios han sido establecidas. De modo que quien se opone a la autoridad, a los establecido por Dios resiste."

61 LUTERO, M. A la nobleza cristina de la nación alemana (1520). Otro de los pasajes citados es Pedro 213 y ss.: "Acatad toda institución humana, lo mismo al rey como soberano que a los gobernadores."

62 LUTERO, M., La libertad cristiana (1520).

63 LUTERO, M. "Exhortación a la paz en contestación a los doce artículos del campesinado de Suabia" (1525), Escritos Políticos, trad. J. Abellán, ed. Tecnos, 1986, p. 75.

64 "Sobre la autoridad secular: hasta donde se le debe obediencia (1523)", Escritos Políticos, cit., p. 50. M. Lutero, “Exhortación a la paz..., Escritos Políticos, cit., p. 90. 
tutelaba la Iglesia con su espada espiritual. En palabras de J. Ma García, la separación completa de lo espiritual con respecto a lo terrenal consagraría la autonomía propia del Estado moderno pero también reforzaría el "derecho divino de los reyes" ${ }^{65}$, sometidos sólo a sí mismos y a Dios de modo inmediato, y no a través de la Iglesia.

\subsection{Grocio y la teoría del 'dominio eminente'}

El protestante Grocio (1583-1645) es deudor de esta concepción tan opuesta a la propia de la Escuela Española. De hecho, es el jurista más notable de la época que abraza la idea dominus directus totius dominio, corolario jurídico lógico de la teología luterana con independencia de que el holandés herrante creara otras formas no teológicas de fundamentación dentro de su plan secularizador del Derecho de gentes.

\subsubsection{Libertad natural, pacto social y soberanía como propiedad}

La editio prínceps de De Jure Belli ac Pacis es de $1625^{66}$. Contiene una compleja teoría política en los libros I y III. En el Lib. I Cap. III VIII refuta la idea de que la soberanía resida siempre en el pueblo ${ }^{67}$. Se opone a la dogmática del pacto apasionadamente ${ }^{68}$. Para llegar a esta conclusión, cuestiona la existencia de libertades naturales del individuo intangibles a transacción: "todo el mundo tiene el derecho de esclavizarse a sí mismo a quien quiera como propiedad privada" ${ }^{69}$. La carga contra el pensamiento lascasiano (y a la Neoescolática española $)^{70}$ sobre los límites del pacto es in totto:

65 GARCÍA MARÍN, J. M., “La doctrina de la soberanía del monarca (1250-1700)”, Fundamentos: Cuadernos monográficos de teoría del estado, derecho público e historia constitucional, núm. 1, 1998, pp. 21-86.

${ }_{66}$ En latín GROTIUS, De iure belli ac pacis, libri tres, vol. 1, Clarendon Press, 1925. Recoge una reproducción fotográfica de la edición de 1646. Traducciones al español propias tomando como referencia el texto en latín y la traducción al inglés de Fr. W. Kelsey, GROTIUS, De iure belli ac pacis, libri tres, vol. 2, Clarendon Press, 1925.

67 La primera crítica de la teoría del pacto de Grocio la hizo Ch. ROUSSEAU, Le contrat social, I, 2. En el s. XX: G. DEL VECCHIO, Lecons de philosophic du droit, Sirey, Paris 1936, p. 64; D. F. SCHELTENS, "Grotius' Doctrine of the Social Contract", Netherlands International Law Review, vol. 30, núm. 1, pp. 43-60, y toda la bibliografia citada.

68 GROCIO, De Iure bellis... op. cit. Libro I, Cap. III, VIII, 1.

69 Ibid. invocando el derecho romano y hebraico.

70 Cita a Fr. de Vitoria y a B. de Ayala e n el Prólogo, pár. 37 y 38. Vide A. RODRÍGUEZ, La Neoescolástica y las raíces del constitucionalismo, Comunicación a la Academia Nacional de Ciencias Morales y Políticas, 25 de agosto de 2004.

DERECHOS Y LIBERTADES

Número 44, Época II, enero 2021, pp. 167-208
ISSN: 1133-0937

DOI: https://doi.org/10.20318/dyl.2021.5853 
“¿Por qué, entonces, no le sería permitido a un pueblo tener la competencia legal para someterse a otra persona, $u$ otras personas, de tal manera como para transferir completamente el derecho legal a gobernar, sin retener ningún vestigio de ese derecho para símismo. No se puede decir que esa presunción no es admisible, porque no estamos intentado averiguar cuál debería ser la presunción en caso de duda, sino si puede ser hecho legalmente".

Recordemos que el sevillano había escrito una obra ${ }^{71}$, Sobre la libertad de los Indios, que se hallaban reducidos á la clase de esclavos (1552), dedicada a rechazar cualquier argumento que permitiera determinar que los indios americanos hubieran podido ser esclavizados válidamente por los españoles. Refutaba inter alia la validez del título que se hubiera obtenido mediante el propio consentimiento elevado a acta pública del indio persuadido con promesas de protección ${ }^{72}$ por mediar ignorancia o engaño sobre lo que este régimen suponía en derecho español. Tampoco era válido ese consentimiento si conducía a una situación ominosa ${ }^{73}$. Incluso califica como fraudulenta la propia esclavitud practicada por los indígenas mejicanos que se derivaba de la venta de un indígena a otro por un precio ("dos mantas de algodón") ${ }^{\prime 74}$. En general, Las Casas presume toda esclavitud como ilícita -con pocas excepciones-. En contraste, para Grocio, "es odioso traer a colación los inconvenientes que resultan" de esta idea, esto es, del rechazo a la libertad de ceder de modo absoluto las libertades individuales a un tercero, el soberano, puesto que, según este autor, todo modelo de gobierno que se diseñe genera inconvenientes. En realidad, Grocio es un pensador ambivalente en términos de Filosofía política actual.

Es moderno/pluralista porque también afirmó que el pacto social no era la única fuente de los poderes soberanos; existían otras formas válidas de alcanzar la summa potestas ${ }^{75}$; esto es a la par reaccionario; son igualmente jus-

71 Mi intuición como investigador de esta época es que Grocio conocía los escritos de Las Casas y los refuta aquí.

72 Obras de Bartolomé de las Casas, T. I, Paris 1822, Vol. II, a cargo de Llorente J. A, pp. 13 a 14.

73 "Aun cuando los indios consintiesen voluntariamente...no puede V. M. lícitamente darlos...la experiencia tiene acreditado ser lo mismo que condenarlos a muerte cruel", LAS CASAS, "Remedio contra la despoblación de las Indias Occidentales", Obras de Bartolomé de las Casas, T. I, Paris 1822, Vol. I, a cargo de Llorente J. A. p. 299.

74 Ibid. vol. II, p. 27. Para Grocio a la comunidad se llega por impulso natural. Al respecto, A. BRETT, "Natural Right and Civil Community: The Civil Philosophy of Hugo Grotius", The Historical Journal, vol. 45, núm. 1 (Mar. 2002), pp. 31-51.

75 GROCIO, De Iure bellis... cit. Libro I, Cap. III, VIII pár. 6 y 8.

ISSN: 1133-0937

DOI: https://doi.org/10.20318/dyl.2021.5853
DERECHOS Y LIBERTADES

Número 44, Época II, enero 2021, pp. 167-208 
tos moral y jurídicamente un gobierno tiránico que uno democrático ${ }^{76}$. Y es antimoderno también cuando resucita la otra rama de la Escuela de Bolonia que aceptaba una posible cesión de la suma potestas operada por el contrato social como absoluta en términos substantivos y temporales ${ }^{77}$. Como lo hará Hobbes más tarde en De cive (1642) ${ }^{78}$. Cuando el origen de la soberanía está en el pacto social ese acuerdo de transferencia podía ser absoluto en el tiempo y en el modo. Se puede haber autovaciado cada individuo, para él y sus sucesores, de todas las libertades y derechos originarios naturales -hasta caer en la esclavitud-y haberlo hecho con valor indefinido en el tiempo, esto es, para siempre a partir del momento inmemorial en que se hizo. Es válido plenamente someterse sin límites a un tercero en el mundo temporal sin que pueda ser medida "con la mayor excelencia esta o aquella forma de gobierno [en abstracto], con respecto a la cual cada hombre puede tener su opinión".

Según el de Delft cada acto traslaticio ascendente, cuando este sea el fundamento de un poder temporal concreto, puede haber restringido más o menos las libertades individuales originarias, incluso haberlas erradicado completamente; o, desde la otra cara de la moneda, puede haber concedido mayores o menores potestades al príncipe, inclusive poderes omnímodos. Habría que estudiar cada pacto traslaticio para ver si había o no dependencia futura de superioridad entre el poder constituido y el poder constituyente ${ }^{79}$. La atribución de plenos poderes sólo sería revocable en cualquier momento si así se hubiera establecido en el acto de traslación/recepción, como era el caso de los Godos en España, indica ${ }^{80}$. Nada quedaba fuera del comercio al pacto social originario. Su apoyatura más relevante de esta idea es la Política de Aristóteles -repudiado en esto explícitamente por Las Casas- en dónde se afirmaba que algunos hombres son por naturaleza esclavos, esto es, "están dotados para la esclavitud, así que hay ciertos pueblos constituidos de tal manera que entienden mejor cómo deben ser gobernados que cómo gober-

76 Ibid. pár. 13. Similar a Fr. SUÁREZ, De legibus, Libro III Cap. III 167-II, 168-I; Cap., IV 169-II, 170-I. Debió leerlo. En este sentido también A. BRETT, “Natural Right...”, cit., p. 34.

77 No cita fuentes. En tiempos de la Querella de las investiduras otros bolonios sostuvieron que la Lex regia había trasladado la soberanía del pueblo al emperador con carácter indefinido e irrevocable. Entre otros, Irnerio, Accursius, el Hostiense, Faenza y Placentino, perdiendo así el pueblo romano omnis potestas.

78 HOBBES, De cive, Debate, Madrid, 1993, pp. 53, 55, 66-67. Aunque hay importantes diferencias en matices. Al respecto, M. HARVEY, "Grotius and Hobbes", British Journal for the History of Philosophy, núm. 14 vol. 1, 2006, pp. 27-50.

79 Ibid. IX 1.

80 Ibid. XI 3. 
nar". También rechaza que la validez del poder constituido dependa universalmente de que se haya establecido para el bien de aquellos que son gobernados, y que de ahí se derive la superioridad del poder social/constituyente sobre el poder constituido ${ }^{81}$.

El pacto de Grocio, así, es tan minimalista y vacío, como un cheque en blanco; se hace sin ninguna contraprestación del lado de quien recibe la summa potestas. Algo así sería nulo incluso en la teoría del contrato privado que presume contrapartidas. Grocio valida el pensamiento de Lutero de sumisión total al gobierno establecido por otras vías seculares ${ }^{82}$. La consecuencia dimanante de su filosofía política realista es exactamente la misma. Todo esto le conduce, a su vez, al rechazo de la conclusión básica de Las Casas sobre el carácter no patrimonial de la soberanía. Sólo concibe esta posibilidad en los casos ciertos en los que la soberanía se haya conferido al Rey mediante la voluntad del pueblo con ese efecto concreto. En estos supuestos sí regiría la idea de Las Casas según la cual no se podría presuponer la voluntad del pueblo de otorgar el derecho al Rey de alienar su poder soberano ${ }^{83}$. Grocio convalida, en definitiva, los modelos absolutistas existentes y pasados, como justos, y a los que se debía obediencia por igual.

\subsection{Dominio eminente y amnistía}

Las Casas fijó, además, una clara distinción entre jurisdicción, un atributo de la soberanía; y propiedad, un derecho civil, y a través de esa diferenciación, limitó aún más el poder soberano, en especial, para transmitir o alienar derechos sobre un territorio o sobre las propiedades privadas como sucedía con las encomiendas. De este modo llegaba a la nulidad de las encomiendas o de otras decisiones soberanas en las que se dividía y transmitía la soberanía sobre un territorio, como si todo ello fuera una hacienda bajo propiedad del Rey, sin el consentimiento del pueblo. En contraste, y como corolario de su forma de racionalizar el poder soberano como algo potencialmente omnímodo a lo que se podía haber llegado incluso mediante pacto constitucional, Grocio afirma que "en algunos casos el poder soberano se ostenta con plenos derechos de propiedad, esto es en patrimonio", tratando así a las personas

\footnotetext{
81 Ibid. VIII 14.

82 Secularizar el su teoria del Derecho es uno de los objetivos expresados en Preámbulo: "non esse Deum, aut non curaria ab eo negotia humana". Ibid. Prolegomena, 11, 13.

83 Ibid. XIII 1.
} 
como propiedades ${ }^{84}$, pudiendo así un soberano enajenar un pueblo entero, en el sentido de transferir libremente como quien transfiere una propiedad, la soberanía perpetua que él ostenta a un tercero como un derecho válido. Empieza así este autor a recuperar, en el marco de su filosofía sobre la titularidad y alcance de las potestades públicas, otra antigua teoría medieval, la del 'dominio eminente', rechazada por La Casas, que fundía en la voluntad soberana plena jurisdicción y propiedad sobre y de las cosas y personas de un Estado. Este andamiaje político-jurídico tiene consecuencias previsibles cuando aborda el tema de las amnistías aprobadas por los soberanos en tratados internacionales, aunque se pueda deducir que sus conclusiones se trasladan a cualquier tipo de amnistía o figura similar de su propio escrito.

En el Capítulo III, del Libro I se aborda la naturaleza del poder público soberano (summi imperii explicatio). Introduce un primer plano de esa integración de la propiedad dentro de la soberanía como algo cosustancial al imperio. El cuadro teórico es rico, como todo en Grocio. Parte de la división del poder político (potestatis civilis) del Estado (civitas) en tres facultades normativas (facultas moralis): nombrar a sus propios cargos públicos, dictar sus propias leyes, y adjudicar según sus propios criterios. Ese poder "se llama soberano cuando sus acciones no están sujetas a control de ningún otro poder de tal modo que no puede ser anulado por el arbitrio de ninguna otra voluntad humana salvo su propia potestad soberana (summa postestate) o la de sus sucesores" ${ }^{85}$. Así, el poder soberano, sea quien fuere el que lo ejerciere, dicta leyes y adjudica disputas, siguiendo la máxima de Ulpiano princeps legibus solutus est y quod principi placuit legis habet vigorem $^{86}$ : su voluntad no queda sometida a ninguna otra voluntad temporal siendo ésta válida como se manifieste en cada momento (voluntare mutare licet). Pues bien, en esa summa potestate está integrado, per se, un derecho especialísimo cuando actúa en su capacidad pública (publica sunt actiones): "in quibus comprehenditur \& dominium eminens, quod civitas habet in cives \& res civium as usum publicum" ${ }^{87}$. Es decir, forma parte integrante del poder soberano básico, sea como se hubiere constituido, la propiedad suprema sobre cosas y personas para la 'utilidad pública', al igual que integran esa soberanía básica el derecho a hacer la guerra, la paz o los tratados ${ }^{88}$. Hay algo así de ordinatio ad unum

\footnotetext{
84 Ibid. XII 1.

85 Ibid. Libro I Cap. III VII 1.

86 Digesto, I, III, 31; e Instit. I, II, 6.

87 GROCIO, De iure belli, cit. Lib. I, Cap. III, VI. 2.

88 Ibid.
} 
agustiniana en este forma de modelar el poder soberano; una subordinación de todo a la unidad a través de la soberanía, como Dios une en su persona todo el gobierno de los cielos.

\subsubsection{Características del dominio eminente}

Este 'dominio eminente', como plano integrante objetivo de la summa potestas guiada hacia la utilidad pública, no es para Grocio un modo de ejercer castigo contra alguien como consecuencia de un acto ilícito previo, sino propiamente un derecho a limitar derechos particulares para dar satisfacción a la utilitas publicae. No requiere ofensa para su ejercicio. No forma parte integrante del ius puniendi. Es derecho superior soberano de propiedad, ejercitable por razón de utilidad pública cuando exista una relación de superioridad entre el que ejerce ese dominio y el que ostenta el derecho así limitado o anulado, cualquier súbdito bajo su jurisdicción ${ }^{89}$. La publicam utilitatem es además diferenciada propiamente del estado de necesidad (summa necessitate), que también justificaría esa destrucción o pérdida de la propiedad por el particular ${ }^{90}$, lo que le daba el mayor efecto expansivo posible. Declarada la utilidad pública el derecho de propiedad suprema se tenía sobre todos los bienes, derechos y personas, aunque su ejercicio, al no ser punitivo, daba lugar a una obligación del Estado que creaba un derecho nuevo sustitutivo en el patrimonio del perjudicado: la obligación de resarcir al ciudadano por el daño recibido a sus derechos que no emergía como castigo por sus actos ilícitos previos ${ }^{91}$. El dominio eminente así es la categoría general que otorga poderes al soberano para expropiar bienes de los particulares por la utilidad general ${ }^{92}$. En fin, en el desarrollo de su doctrina del dominio eminente Grocio hace otra interesante distinción entre el titular del mismo y quien lo ejerce en su nombre: "ius superemines dominio in res subditorum, quod civitati competit \& ejus nomine a summam potestatem habente exercetu." 93. Así, este derecho le pertenece al Estado en su conjunto ('civitas habet', 'civitati competit') pero es activado en su nombre por quien ejerce los poderes máxi-

89 Id. Lib. II Cap. XIII, XX 3; y Cap. XIV, VII, donde distingue castigo de 'supereminentis dominii'.

$90 \quad$ Ibid Lib. III Cap. XX VII.

91 Ibid. Lib. II Cap. XXI, XI; también Lib III XX VII 2, con más desarrollo.

92 'Eminent domain' es uno de los términos en los EEUU para la expropiación, v. Kohl v. US, 91 U.S. 367 (1876).

93 Ibid. Libro III, Cap. XIX, VII 1. 
mos. El soberano que ve maximizados sus poderes alegando la mera utilidad o interés público, pero que en él está exento de responder por su uso ante la civitas porque no deriva su potestad máxima de un pacto social, o lo hace sólo de modo muy remoto y a título de derecho ya propio. Esta teoría la proyectó para validar la figura de la amnistía.

\subsection{Amnistía y dominio eminente}

\subsubsection{Internacional}

Grocio en su Libro III recoge un conjunto de reglas del ius in bello. En su Capítulo X pár. IV afirma que cuando la guerra se vuelve injusta por razón de su conducción es responsabilidad del Estado, de los oficiales y de los soldados responder por los males causados. Pero el Capítulo XX, pár. VII del mismo libro, titulado "Sobre la buena fe de los Estados por la que la guerra finaliza" descubre el contrapunto realista y generalizado por la práctica entre los Estados: "las guerras finalizan bien cuando terminan con el perdón". Es la salvaguarda de la "utilidad pública" ejerciendo el "dominio eminente" lo que va a posibilitar este feliz final. Evitar el gran daño del reino como señalaban también las Partidas. Al "organizar la paz”, dice, “¿qué conclusión con respecto a la propiedad de los súbditos puede ser adoptada por reyes que no tienen otro derecho sobre la propiedad de sus súbditos que el heredado en el poder real?". Y responde: "la propiedad de los súbditos pertenece al Estado bajo el derecho de dominio eminente", por lo que en consecuencia, "puede usar la propiedad de los sujetos e incluso destruirla o enajenarla... en favor de la utilidad pública; y para el beneficio público de esas mismas personas que formaron el cuerpo político." Agregando que cuando esto sucede "el estado está obligado a reparar a expensas públicas el daño a quienes pierden sus propiedades..."

Esta situación se extiende en el pár. XV tanto sobre reclamaciones patrimoniales como penales, públicas o privadas "por los daños causados por la guerra" y "en caso de duda, se presume que los beligerantes tenían la intención de llegar a un acuerdo tal que ninguno de los dos sería condenado como culpable de injusticia". ¿A qué utilidad pública se refería? El pár. XVII es claro, el "temor a que la paz no sea una paz perfecta si deja las viejas causas de la guerra". Esta utilidad pública, obviamente, no debía ya coincidir necesariamente con la protección de las libertades naturales de los súbditos pues esto alcanza incluso (par. XVIII) al derecho "de las personas privadas a infli- 
gir castigos" a pesar de que estas reclamaciones se podrían llevar a cabo posteriormente en tribunales que juzgaran meramente a individuos concluida la guerra, dado que "los castigos siempre causan odio" y cabe entender "que este derecho también puede entenderse como renunciado" por el soberano. La figura de la amnistía de Grocio representa así la apoteosis del poder soberano liberado de límites que puedan emanar de las libertades naturales del individuo de las que parte Las Casas en su teoría política. Grocio presume la renuncia a todas las libertades naturales; Las Casas presume su vigencia salvo pacto expreso en contra.

Grocio cita como fuente de esta idea al jurista germano Andreas von Gail en Observationes practicae (1578) ${ }^{94}$. Este autor, en efecto, afirmaba el derecho del príncipe a disponer de los bienes de sus súbditos como parte de los arreglos para la paz para evitar daños mayores. Pero Gail no apela como fundamento de esta afirmación al 'derecho eminente'. Si habla de la 'communem et publicam utilitatem" y de la doctrina del mal menor; evitar los males mayores que se derivarían de la continuación de la guerra. De hecho, la doctrina del 'dominio eminente' se debe atribuir propiamente al decretalista Enrique de Sousa (1200-1271 d. C) -el Ostiense u Hostiense- que también citaba Las Casas cuando diferenciaba 'jurisdicción' de 'dominio o propiedad' para calificar su idea del 'dominio eminente' como un magnus error puesto que el rey no es dominus in suo regno a título de propiedad sino solamente de jurisdicción. Grocio es por ello el jurista más notable de la época que abraza incondicionalmente la afirmación de que el Rey es dominus directus totius dominii, tanto público como privado. Es paradójico saber que el Ostiense, formulador de la doctrina del 'dominio eminente', nunca extendió sus efectos a la cuestión de la cancelación mediante los acuerdos de paz de los daños sufridos por el pueblo durante la guerra: "Principes per se non potest componere de damnis datis populo occassione guerrae... quia neotium regis negotium universitatis regni, et ideo etiam sufficit consensus partis maioris maiorum regni." 95

¿Qué es así la doctrina del "dominio eminente"? Lo más opuesto a la doctrina de Las Casas. La potestad omnímoda del soberano para limitar o anular los derechos y libertades naturales del individuo en caso de necesidad o de mera 'utilidad pública', disponiendo de ellos; una idea incluso mucho

94 En Annotata Caput XX par. VII del Lib. III, p. 569, como Gail II obs. 57, es la Observatio LVII.

95 Hostiensis, In secundum Decretalium librum commetaria.(1581), tit. I, De iure iurando II, 24, cap. 18, n. 3, p. 130. 
más abstracta, dinámica y radicalmente política que el "merecimiento", la "gracia", el "perdón", o la "misericordia" de las Partidas: la posterior 'razón de Estado' impenetrable a la que accedían los sacerdotes laicos definidores del 'bien común'.

\subsubsection{Interna}

Tal concepción expansiva de la soberanía también surtía efectos en el plano del Derecho interno con respecto a perdones, amnistías, gracias, etc. Se desarrolla en el Libro II Cap. XX De poenis, especialmente en párs. XXI-XXVII. Se pregunta allí si es lícito condonar lo prohibido (veniam dare liceat interdum) y rechaza todo argumento contrario. La pena debida es una obligación del penado, pero no un deber de quien debe imponerla, sino una facultad de hacerlo concedida tanto por el derecho natural como por las leyes penales positivas (pár. XXI). Esto es así por distintos motivos, uno de ellos, por la conexión que hay siempre entre la pena y sus fines. Se puede ahorrar la pena si los fines para los que se planteó el castigo no son luego necesarios; o si se han vuelto menos relevantes frente a otros fines emergentes; o si se pueden alcanzar los mismos fines por otros medios menos lesivos que los inicialmente previstos al determinar el castigo de una conducta (pár. XXII). El 'bonum publicum' podía hacer que se omita el castigo exigido (pár. XXIII). Y esto es así (par. XXIV) aunque el legislador esté obligado por sus propias leyes, i. e., cuando la pena es de carácter público. La razón en este caso remite indubitadamente a la concepción del poder soberano como poder legislativo, que "puede derogar por completo la ley", ergo, "como el legislador tiene el poder de derogar la totalidad de una ley, así en el caso de alguna persona en particular, o acción individual, puede también relajar su rigor, permitiendo que permanezca en otros aspectos, como estaba antes" ${ }^{96}$. Así, con carácter general "rectoribus pro arbitrio punienda aut dissimulanda relinquerentur" 97 . Es decir, el que ejerce los máximos poderes puede castigar su comisión o 'dissimulanda', esto es, no perseguir los delitos bajo su jurisdicción. Otra vez no se señala si se está refiriendo al perdón o a la amnistía, en sentido propio, pero toda la redacción tiene un aroma de discrecionalidad máxima. La amnistía interna, con sus efectos actuales, encuentra expreso acomodo en otro lugar del escrito.

96 Pár. XXIB.

97 Libro II Cap. XXI De poenarum communicatione, III. Id. ibid. XXV-XXVI. 
El Libro III hace mención frecuente a las guerras de carácter interno y las reglas aplicables a las mismas. Aquí interesa la que emerge en su Capítulo XIX titulado 'Sobre la buena fe entre los enemigos'. Se pregunta en qué medida en general se deben respetar las promesas o compromisos que se alcance con los enemigos en las guerras. Responde, para las guerras internacionales, que deben ser respetados, incluso si se libran contra un tirano, o si se ha hecho a quien ejerce la piratería, calificada por Grocio como delicta iuris gentium. ¿Pero qué sucede con las guerras internas en las que el enemigo es la parte rebelde de un Estado, los subditos bellantes? La respuesta (pár. VI) es que no se puede castigar ni a rebeldes ni a desertores si media promesa, para finalizar la guerra, de que no serán castigados por su rebelión o por los actos realizados durante la contienda, incluso si no tuvieran un derecho o causa legítima para luchar contra el soberano. Curiosamente para la justificación de estas amnistías Grocio con arrojo y pragmatismo crea una excepción a la doctrina del 'dominio eminente'.

La invocación de esta teoría tiene aquí contraindicaciones severas. Una vez conseguida la paz mediante el acuerdo de amnistía acordado con los rebeldes podría privarla de efectos si con las aguas ya calmadas el soberano invoca su derecho de 'dominio eminente' frente a los derechos que emanasen de la amnistía recogida en el acuerdo celebrado con los sediciosos que ya habían vuelto a quedar plenamente bajo su soberanía (pár. VII). Si rige el dominio eminente, podría luego eliminar el derecho a la amnistía de los rebeldes, como con cualquier otra posesión o derecho, invocando la 'utilidad pública'. Pero entonces, reconoce que si estos acuerdos de paz internos pudieran ser anulados de tal modo, "no habría ninguna esperanza de acabar una guerra excepto mediante la victoria de una de las partes". Por lo que concluye que no cabría el recurso al derecho de dominio eminente para hurtar los efectos de la amnistía dada acordada con los rebeldes puesto que este derecho no se debe ejercer de modo indiscriminado (non promiscuo competere) sino para el beneficio de la comunidad ('communiter expedit') y estos pactos se han realizado para la conservación del Estado que es el bien común. Además, habría una imposibilidad de compensar el ejercicio del dominio eminente si esto eliminaba la amnistía puesto que los rebeldes serían ejecutados, algo materialmente imposible de compensar a los mismos, que era la otra condición para dotar de validez a las expropiaciones de derecho. No obstante, el domino eminente, con efectos más limitados, debía seguir siendo el fundamento latente de esa amnistía de los rebeldes con respecto a los súbditos que 
no se rebelaron y sufrieron los daños causados por unos u otros durante la contienda si las amnistías internas para este tipo de guerras cubrían, como las amnistías internacionales, no sólo los delitos contra 'gentis et patria', sino también los daños privados causados durante la guerra al resto de súbditos no rebeldes. La ausencia de derechos de estos terceros particulares para reclamar por los daños causados por las acciones de la guerra atribuibles a los rebeldes sólo podía explicarse bajo la doctrina del derecho eminente; el Rey les habría despojado de los mismos por utilidad pública, y habría debido, por consiguiente, reparar el daño a expensas públicas.

\section{PAZ DE WESTFALIA (1648) Y OTROS TRATADOS}

Las guerras, de todo tipo, continuaron en gran número, y tras ellas, los tratados de paz, y con los tratados de paz ¿la doctrina de Grocio o de las Casas respecto a la amnistía?

\subsection{Amnistías grocianas (ss. XVII a XIX)}

Predominó absolutamente Grocio. Los principales tratados de paz celebrados desde el s. XVII incorporaron de modo casi invariable cláusulas que, con uno u otro alcance, recogen la "amnistía", "perdón", u "olvido", o todo ello junto, de los crímenes y daños que se hubieran cometido por los beligerantes en los tiempos de la guerra que persiguen cauterizar ${ }^{98}$. Por citar algunos notorios, en el s. XVII se encuentran cláusulas de amnistía en el art. 2 del Tratado de Paz, Alianza y Comercio entre España e Inglaterra, o Tratado de Londres (1604) ${ }^{99}$; en el art. III del Tratado de Nimega (1678), entre Francia y las Provincias Unidas ${ }^{100}$ que pone fin a la Guerra de Holanda (1672-1678); o en el art. III del Tratado de Riswick de 1697, entre el Rey de España y el Emperador ${ }^{101}$. Todos ellos resultan interesantes en la medida en que son va-

98 F. Z. NTOUBANDI, Amnesty for Crimes against Humanity Under International Law, 2007, M. Nijhoff, pp. 16-18.

99 Tratado Paz, Alianza y Comercio entre Felipe III, los Archiduques Alberto e Isabel Clara Eugenia, y Jacobo I, ABREU, Colección ... cit. Parte I, 1740, p. 249.

100 Tratado de Paz, Alianza y Neutralidad entre el Rey Cristianísimo de Francia y los Estados Generales de las Provincias Unidas, hecho en Nimega el 10 de agosto de 1678, v. Prontuario de los Tratados de Paz, alianza y Comercio de España, Parte I, II, III, Madrid 1752, p. 179.

101 Tratado de Paz, Alianza y Amistad entre España y el Imperio Sacro Germánico, 20 de septiembre de 1697, en Prontuario de los Tratados de Paz, alianza y Comercio de España, Parte I, II y

DERECHOS Y LIBERTADES

ISSN: 1133-0937

Número 44, Época II, enero 2021, pp. 167-208

DOI: https://doi.org/10.20318/dyl.2021.5853 
rias las disposiciones de sus textos que concretan con precisión de detalle la amnistía que puede figurar primero sólo de modo muy genérico.

El art. III del Tratado de Nimega, por ejemplo, es bastante parco. La paz se cierra "sin sentirse de las ofensas, ò daños que han recivido, assi en lo passado, como con motivo de dichas guerras". Pero los efectos jurídicos de esta regla se fijan en el resto del articulado asociados. Así: a) Aquellos a quienes se les hubiera embargado o confiscado bienes con ocasión de la guerra o sus Herederos, debían ser restituidos en la posesión de los mismos sin necesidad de recurrir a la Justicia, quedando anulada cualquier decisión fiscal o judicial que se hubiera producido al respecto (art. V). Esta cláusula es idéntica en sus efectos a la del Tratado de Câteau-Cambresis y restituía en sus derechos a los que, por decantarse por uno y otro bando durante la contienda, fueron objeto de embargo o confiscación de sus bienes y derechos civiles; b) Y todos los prisioneros de guerra hechos debian ser entregados por una y otra parte "sin distinción, ò reserva, y sin pagar rescate alguno" (art. XI), esto es, con indiferencia de las conductas que hubieran realizado en campaña. El Art. XIV del Tratado de Riswich contiene otra disposición de liberación incondicional de los presos de guerra e incorpora artículos de restablecimiento en todos sus derechos a los súbditos de ambas partes (arts. XVIII. XIX y XX) anulando cualquier sentencia o juicio emitido "como no se huviessen dado, ni pronunciado". Pero la cláusula absoluta de amnistía, la cláusula de cláusulas, la que refleja perfectamente en del Derecho internacional clásico el triunfo de Grocio se encuentra en la Paz de Westfalia (1648).

\subsection{Art. II del Tratado de Osnabrück (1648)}

Tras la proclamación de la paz perpetua entre todas las potencias firmantes -Europa en su conjunto- el Art. II del Tratado de Osnabrück (1648) establece que:

"Habrá de ambas partes un perpetuo olvido, y perdón general de todas las hostilidades, que desde el principio de estos movimientos se han hecho recíprocamente, en cualquier lugar, o modo, por una, u otra parte; de suerte, que ni por causa, o pretexto de ellas, o de alguna otra cosa, haga uno a otro de aquí en adelante, o permita que se haga alguna hostilidad, o perjuicio, molestia, o

III, Madrid 1752, pp. 317 y ss. Misma fecha y lugar para Traité de Paix entre Louïs XIV, Roi de France, et les Seigneurs Etats Generaux des Provinces-Unies des Païs-Bas, art. II con cláusula de amnistía. DU MONT, Corps Universel..., cit., Tome VII, Partie II, pp. 381-383. 
impedimento, en cuanto a las personas, Estado, bienes, o seguridad, por sí, o por otros, oculta, o manifiestamente, directa, o indirectamente, por vía de derecho, o de hecho, en el Imperio, o en alguna otra parte fuera de él, no obstante cualesquiera pactos que hayan precedido en contrario; sino que reciprocamente todas, y cualesquiera injurias, violencias, hostilidades, daños, y gastos hechos por una, y otra parte antes, y durante la Guerra, de palabra, por escrito, o de hecho, sin consideración de personas, o cosas, serán abolidos de tal modo, que todo lo que con este pretexto pudiere pretender uno contra otro, quedará en perpetuo olvido" 102 .

Los hechos amnistiados no son, como es notorio, de una naturaleza distinta los que podrían ser calificados como crímenes internacionales hoy -o entonces-. El ser humano conserva en el interior esa pulsión hacia el primate que somos, apenas oculto bajo micras de corteza gris, y siempre dispuesto a emerger si se dan las circunstancias. Sin embargo, el uso de las palabras "perpetuo olvido" y "perdón", remite a la idea del mayor rango de efectos normativos posibles: el perdón cristiano de los condenados por estos actos durante la guerra, de uno u otro lado, y consiguiente liberación espiritual en la tierra; el olvido griego o 'amnesia' de los hechos no enjuiciados; el archivo jurídico del Rey Sabio de cualquier proceso pendiente de solución. Todo modo de reparación particular o público quedó anegado, sometido al bien común de la "paz pública" dispuesta por los soberanos, sin que jamás se solventara proceso de consulta a los súbditos. Para los firmantes, cualquier reclamación de Estado a Estado, o de los particulares entre ellos, o de un particular frente al Estado, podía suponer una amenaza tal a la paz tan arduamente lograda que no merecía la pena ser considerada. Se debía evitar, por encima de todo que se "haga alguna hostilidad, perjuicio o molestia” entre los firmantes. Es muy claro también, en este sentido, el art. 4 del Tratado de los Pirineos (1659), colofón final de la Paz de Westfalia, por el que quedó prohibido tanto "manifestar ningún género de sentimiento de todas las ofensas, y daños, que pudieren haber recibido durante la Guerra" como "hacer averiguación de ello por justicia, o de otro modo, con cualquier pretexto que sea" ni pueda nadie ${ }^{103}$.

102 Tratado de Paz de Osnabruch, 14 oct. 1648, J.A. ABREU, Colección... cit. Parte V, 1750, p. 476 y ss.

103 Tratado definitivo de Paz y Comercio entre las Coronas de España y Francia, o Tratado de los Pirineos, 27 de noviembre de 1659, en J. A. ABREU Y BERTODANO, Colección... cit. Parte VI, 1751, p. 121.

DERECHOS Y LIBERTADES

ISSN: 1133-0937

Número 44, Época II, enero 2021, pp. 167-208

DOI: https://doi.org/10.20318/dyl.2021.5853 
Se trata en todos los casos, atendiendo a su ubicación principal en los tratados, de una pieza jurídica clave para conseguir la paz, el cierre definitivo de las hostilidades, cuyas condiciones se cerraban en los tratados. La ratio que anida en su aprobación no es en nada distinta a la que abogaría todavía hoy día en favor de la incorporación de amnistías a procesos de pacificación interna o de transición democrática y no tuvo en cuenta las razones de Las Casas al formular su teoría limitativa. Se debía evitar que la herida de la guerra volviera a abrirse. La paz perpetua, nombre que adoptarán muchos de los tratados de paz de éste período y de otros posteriores, se concluye a través de una olvido perpetuo y completo, ajustado por los soberanos mediante la concesión de menguas y acrecimientos de territorios soberanos de uno $\mathrm{u}$ otra parte; el acuerdo de matrimonios de conveniencia entre nobles herederos para asegurar títulos sucesorios futuros; y la renuncia por medio de las cláusulas de amnistía a la reclamación o castigo de cualquier otra responsabilidad, pública o privada, patrimonial o criminal, derivada de las causas o consecuencias de la guerra que no se hubiera fijado expresamente en el tratado de paz, junto con la liberación de los presos de guerra de los contendientes, cualquiera que hubieran sido sus conductas durante la contienda armada.

Cierto es que no todos los tratados internacionales de paz del período clásico del derecho internacional contienen cláusulas de amnistía. Ilustrativamente, no se ha encontrado cláusulas de amnistía en el Tratado de Campo Formio (1797); o en los Tratados de Lunéville y de Amiens (1801). Pero, en realidad, como explicaba E. Vattel (s. XVIII), esta ausencia de cláusulas de amnistía no era concluyente en cuanto a la existencia o no de amnistías de facto. El jurista suizo hizo suyas las razones y alcance de las amnistías de paz que leyó en Grocio y presumió de modo general su existencia en caso de silencio, "aunque en el tratado no se dijese una palabra, la amnistía se comprende en él necesariamente por la naturaleza misma de la paz." ${ }^{104}$ En el siglo XIX Pando reitera sin cambios la posición, añadiendo un matiz que da aún más sentido aún a estas cláusulas. Los tratados de paz son una transacción que no persigue resolver quién tenía justo título para iniciar la guerra. Son simplemente un compromiso entre beligerantes sobre lo que cada cual acepta para abandonar la persecución de sus pretensiones por la fuerza ${ }^{105}$.

104 E. VATTEL, El Derecho de Gentes ó Principios de la Ley Natural, Tomo II, Madrid, 1834, p. 278.

105 J. M. DE PANDO, Elementos del Derecho Internacional, Segunda Edición, Madrid, 1852, §. CCXXII, pp. 581-582. 


\section{REFLEXIONES GENERALES}

La sombra de las amnistías, como la del ciprés, es alargada. En cualquiera de los contextos históricos al que se acuda desde el III Milenio a. C. consta la aprobación de amnistías. Cada uno de ellos generó pautas propias de fundamentación de la validez de las amnistías: el acuerdo de la Asamblea, el interés general y la ética del buen gobierno en Atenas; la summa potestas del pueblo, el Senado, o del Emperador romanos, etc. Llegados al tramo medieval se percibe un momento de recombinación de todas estas formas de fundamentación pasadas por el tamiz del pensamiento cristiano. Se busca entroncar su validez también en la conciencia moral cristiana de los príncipes, sin renunciar a la invocación de las más antiguas razones ligadas a la simple oportunidad de su concesión para preservar el interés general. La orientación moral del poder soberano que inician los escritos de teólogos como San Agustín (s. IV-V), “cuál y cuán verdadera sea la felicidad de los emperadores cristianos... Si conceden perdón no para dejar impune la justicia, sino por la esperanza de la enmienda" 106 pasó a ser un modo complementario de fundamentar el poder de conceder amnistías. Superpuesto a ese acervo milenario asomaron las dos primeras especulaciones teóricas sobre la validez de las amnistías fijadas en tratados internacionales en los siglos XVI-XVII d. C.

Para su doctrina Las Casas partió de su teoría de las libertades naturales y el pacto social ascendente. La soberanía era propia del pueblo; recibida por los reyes de modo inmediato de manos del pueblo; el acto de traslación era el libre consentimiento de los hombres; y la traslación no era absoluta ni temporal ni sustantivamente. Las libertades originales permanecían vivas salvo en lo afectado expresamente por el pacto traslaticio, sin que se pudiera presumir una entrega al soberano de la propiedad junto con la jurisdicción. Esto implicaba la necesidad de volver al cuerpo social en cualquier momento futuro en el que se quisiera aumentar las atribuciones cedidas a quien ejerciera la summa potestas. Como el pacto original no se extendía expresamente a la capacidad para disponer de derechos privados las amnistías que se colocaban en los tratados internacionales eran nulas si no habían sido aceptadas expresamente por todo el cuerpo social que, por mor de su adopción, iba a verse privado o limitado en sus libertades fundamentales.

Por el contrario, Grocio extendió un cheque en blanco al soberano temporal para acordar amnistías en los tratados de paz. Todo poder público ejercido en la tierra emanaba de Dios, fuera cual fuera el origen de su titularidad concreta, y la summa potestas se transformaba no sólo en el ejercicio de las máximas competencias legisla-

106 SAN AGUSTÍN, La Ciudad de Dios, Libro V, Capítulo XXIV.

DERECHOS Y LIBERTADES

ISSN: 1133-0937

Número 44, Época II, enero 2021, pp. 167-208

DOI: https://doi.org/10.20318/dyl.2021.5853 
tivas, judiciales y ejecutivas, sino también en un 'dominio eminente' o propiedad superior para disponer -donar, alienar, suspender la posesión, expropiar- sobre cosas y personas que le permitía libremente, para velar por la 'utilidad pública', disponer de los derechos privados de sus súbditos, con la única condición de compensar el daño causado al súbdito por su ejercicio. Concedió así validez absoluta a las cláusulas de amnistía fijadas en los tratados de paz frente a cualquier tipo de daño y forma de persecución, pública o privada, patrimonial o penal. Incluso acepta la posibilidad de que la amnistía se extienda a hechos anteriores al inicio de la guerra. La existencia de esta cláusula de amnistía debía incluso ser presumida si no se recoge como tal en los tratados de paz. El fin último al que debían subordinarse todos los derechos individuales es lograr una "paz perfecta" que se convierta en esta situación en el interés público esencial. El derecho que ejerce el Estado a través del soberano para garantizar esa "utilidad pública" es el "dominio eminente". Y crea una obligación sustitutiva de compensar el daño que se efectúa al particular al proceder de este modo en beneficio del interés general. ¿Cómo trató la Historia las ideas de Las Casas? Cayeron en el olvido. Durante siglos predominó la teoría absolutista del 'dominio eminente' relativa a la configuración de los poderes políticos que se extendió a la concepción de la soberanía de los Estados democráticos que emergieron a partir del s. XVIII. Es el origen de la teoría de la razón de Estado y de la institución de la expropiación de bienes privados por el interés general. Llevemos este conocimiento ahora al gaseoso presente.

En términos éticos y políticos hoy día las amnistías se avalan o discuten mediante dos grandes argumentaciones antagónicas con posturas eclécticas entre medio y, a su vez, en cada extremo, con diversidad de matices. Una doctrina del mal menor necesario, impregnada de utilitarismo, concede prioridad al logro de la "paz", es decir, el cese de hostilidades armadas para cerrar una situación previa de conflicto, por encima de otras consideraciones relativas, por ejemplo, al castigo de una u otra parte en el mismo. Esta doctrina dominó a nivel académico e institucional hasta mediados los noventa. El logro del fin de esa violencia armada o imposición política de unos contra otros, en una circunstancia extrema de vulneración de los derechos más básicos de la persona -la guerra, y en un escalafón inferior, la dictadura con uno y otro sesgo- es el primer objetivo o interés general a satisfacer para alumbrar condiciones más favorables para la vida colectiva e individual. Su obtención debe afrontarse dejando a un lado afrentas pasadas y de ahí que se renuncie a la persecución de hechos que, en circunstancias ordinarias, debieran ser castigados. El mal menor, así, no se desliga nunca de la protección de los derechos humanos. Entiende que impedirá su vulneración sistemática a futuro, puesto que las guerras -o las dictaduras- son un contexto de limitación máxima de los mismos. Y la amnistía es una condición sine qua non para

ISSN: 1133-0937

DOI: https://doi.org/10.20318/dyl.2021.5853
DERECHOS Y LIBERTADES

Número 44, Época II, enero 2021, pp. 167-208 
facilitar el cese de las hostilidades. El antiguo puente de plata al enemigo que se plantea retroceder.

La otra corriente la denomino doctrina de la reparación íntegra. Se centra en abordar estas situaciones desde la protección más completa posible de los derechos de las víctimas como único mecanismo de salida a largo plazo del conflicto. Observable especialmente en las dos últimas décadas, parte de un escepticismo general respecto al valor político real de la concesión de amnistías, muy especialmente cuando se proyecta sobre crímenes internacionales $u$ otras graves violaciones de derechos humanos, aunque cuestiona en general todo lo que no sea la persecución penal de los responsables con el fin de evitar la impunidad. Estrechamente vinculada a movimientos y asociaciones no gubernamentales centradas en la protección de los derechos humanos y a corrientes de izquierdas, las amnistías para ellos han dejado de ser una expresión de "sabiduría política" o la solución natural incuestionable para la transición de una situación de violencia hacia la paz. La lucha contra la impunidad por la vulneración de derechos humanos sería la mejor vía para alcanzar una transición con más cotas de justicia con respecto a los derechos de las víctimas y más aceptable con el paso del tiempo.

Obviamente, no se puede trabar, sin más, paralelismos directos entre éstas y las antiguas doctrinas de Las Casas y Grocio. Ni la doctrina del 'mal menor' o del 'interés general' invoca la doctrina del dominio eminente como fundamento para su ejercicio; ni Las Casas defendió nunca una prohibición absoluta de las amnistías; sólo entendía que no figuraban en el pacto social originario y por ello debían ser aprobadas por el pueblo que iba a renunciar a la reparación de la vulneración de sus derechos y libertades fundamentales. Pero, por sus resultados y trasfondo, el pensamiento de Grocio y Las Casas sólo podría ser subsumido en la posición del 'mal menor' o del 'interés general', nunca en la rigorista de la reparación íntegra. Las Casas avala la amnistía incluso por vulneraciones graves de libertades naturales siempre que emerja de un pacto social explícito. Cumplido este requisito, tanto para abordar la paz en guerras internacionales como en otros fenómenos de violencia extrema interna, una amnistía absoluta sería válida. El 'dominio eminente' no apeló tampoco sin más a un si libet licet tiránico: era una potestad soberana reglada. Debía demostrar la utilidad pública de la amnistía y asegurar fórmulas de reparación a quienes veían cegados sus derechos a la reparación a costa del Estado por los daños sufridos a través de los actos que quedarían impunes, aspecto este al que no prestó atención Las Casas, cuya teoría del consentimiento parece omnímoda en este sentido; no habla en ningún caso de la necesidad de reparar a quien perdía válidamente sus derechos como fruto de la actualización del pacto social que aprobaba expresamente la amnistía. En contraste, la paz social que persigue 
la doctrina de la reparación íntegra se inhibe de la responsabilidad primera -que no exclusiva- que deben asumir los negociadores y líderes de una sociedad dividida o en guerra: obtener con la mayor brevedad de tiempo un estado de paz posible. Por el contrario, la doctrina del mal menor necesario, o del interés público, no omite el tratamiento adecuado de medidas alternativas de reparación o compensación de las víctimas, no penales, con el límite de que no afecten la precariedad de la paz obtenida puesto que es consciente que esta omisión lastraría la construcción del espacio público social y político compartible por una amplia mayoría. Es difícilmente conciliable el bien de la mayoría a expensas de una parte especialmente perjudicada por los hechos que se amnistían.

Siempre es factible, así, recorrer caminos intermedios. Entre el "perdón general y el olvido perpetuo" por decisión soberana alejada de un proceso adecuado de maduración y aceptación pública; y la "reparación íntegra" pase lo que pase, fiat iustitia et pereat mundi, existen caminos explorados por el laboratorio de la Historia que ofrecen soluciones pragmáticas. Porque al final de un discurso brillante, ahíto de consideraciones hacia lo más digno de la Humanidad, vuelve la pregunta incómoda, más apegada a lo concreto, a lo plenamente humano con sus defectos cotidianos, después de décadas o años de combate armado o de dictadura, ¿aceptará el líder de un grupo rebelde una tregua, o la cúpula tirana dará pasos firmes hacia una transición a la democracia si vislumbra futura persecución penal? En esas condiciones está por nacer el negociador capaz de persuadirles en favor de la paz invocando los grandes beneficios para la Humanidad derivados de su cambio de statu quo de líder políticomilitar a reo inerme. El conflicto se prolongará y será la fuerza acumulada por uno u otro la lo que decidirá un seguro destino trágico para la sociedad, como sabía Grocio. Todo el tiempo en que se alargue la disputa será un tiempo perdido para los derechos humanos de los individuos del colectivo involucrado. Si el derecho prohibiera las amnistías para hechos lesivos de la dignidad humana se habría entrado en una evolución normativa históricamente ciega y políticamente contraria a la defensa de los Derechos Humanos en un sentido amplio. Condenaría a que todas las guerras o conflictos internos se alargaran indefinidamente y sólo llegaran a su fin mediante la derrota de una de las partes. Jurídicamente no se debe perder de vista que en derecho internacional el primer objetivo de la ONU, según el art. 1.1 de la Carta, es el establecimiento y mantenimiento de la paz internacional. El valor de la protección de la dignidad humana a través del reconocimiento de sus derechos fundamentales se encuentra enunciado también en el Preámbulo pero luego recala en el art. 1.3 de la Carta y lo hace además tras el "principio de libre determinación de los pueblos", recogido en el art. 1.2 de la Carta, y desarrollado en resoluciones posteriores como la 
capacidad de cada pueblo de determinar libremente su condición jurídico-política, como apoyaba Las Casas para dotar de validez a las amnistías.

Más allá de volubles prejuicios ideológicos -en España algunos abogan simultáneamente sin pestañear por la derogación de la Ley de Amnistía de España (1977) y por la aprobación de una Ley de Amnistía para los terroristas de ETA. Pronto lo harán también, si cae una sentencia adversa como es de esperar, en favor de los 'libertadores' de Cataluña-, conviene recordar a Kant: "de la madera torcida de la que está hecho el hombre no puede tallarse nada enteramente recto." ${ }^{107}$ Del cúmulo de ideas parcialmente contradictorias que emergen del pensamiento de Las Casas y Grocio surgen buenas propuestas para elevar esas columnas salomónicas que deben aunar la fuerza de la justicia con la estabilidad de la paz social como las columnas helicoidales de fuste retorcido de nombres Boaz y Jachin que flanqueaban el vestíbulo del Gran templo de Salomón.

Víctor M. SÁNCHEZ Universidad Oberta de Catalunya, Edifici B3, Parc Mediterrani de la Tecnologia, Avinguda Carl Friedrich Gauss, 5, 08860 Casteldefels, Barcelona e-mail:vsanchezsa@uoc.edu

107 I. KANT, Idea para una historia universal en sentido cosmopolita (1784), Ed. Tecnos, Madrid, 1994. 